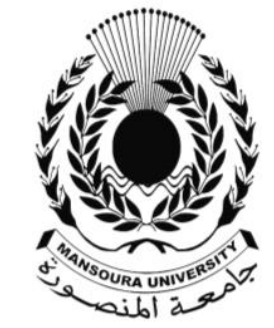

جامعة المنصـورة المانفة

$$
\text { كليـة الآداب }
$$

\title{
رؤية جديدة حول وفاة الخليفة العباسى المهدى فى ضوى دراسة لدرهمين نادرين
}

\author{
sleel \\ أ. أد / محمد هاشم أبوطربوش \\ أستاذ ورئيس قسم الآثار الإسلامية \\ كلية الآداب - جامعة المنصورة \\ مجـلة كلــية الآداب - جامعـة المنصــورة

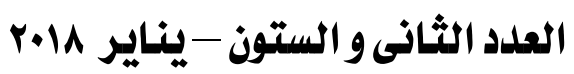




\title{
رؤية جديدة هول وفاة الخليفة العباسى المهدى فو ضوء دراستة لدرهمين نادربين
}

\section{أ.د / محمد هاشم أبو طربوش}

\begin{abstract}
يقدم البحث دراسة لدرهمين للخليفة العباسي المهدي بتاريخ ضرب سنة 179 1هـ ، ينثران لأول مرة .

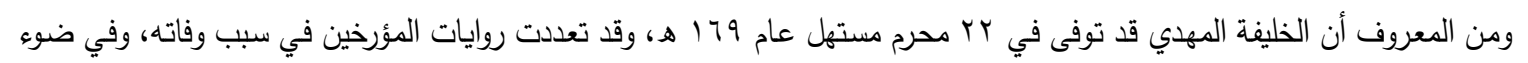

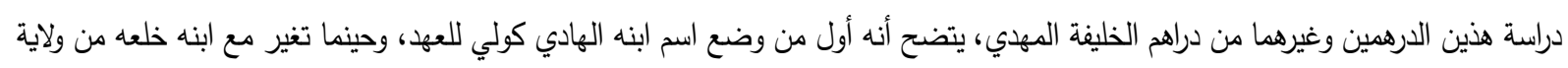

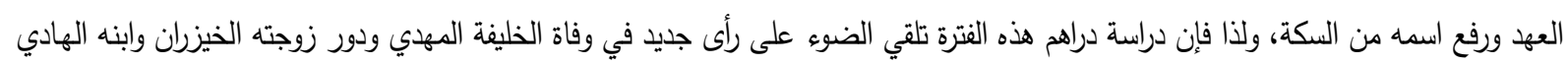
في ذللك
\end{abstract}

\section{Abstract}

The research is a study of two Dirhams of the Abbasid Caliph Al Mahdi. In the research, these two Dirhams that are dated $1690 \mathrm{AH}$ are to be put out in public for the first time.

It is known that Caliph Al Mahdi passed away in 22 Muharram at the beginning of year $169 \mathrm{AH}$ and there were several stories by historians regarding his death. This study examines these Dirhams along with several other Caliphs' Dirhams. It became obvious that Caliph Al Mahdi was the first to put his son's name (Al Hadi) as the crown prince. However when the Caliph turned against him, he ousted the crown prince from the covenant and removed his name from roads.

Therefore, examining these dirhams sheds light on a new perspective regarding the Caliph's death and the role of his wife Al-Khayzuran and his son Al Hadi in his death.

الدولـة فـى الحكـم حـوالي خمسـة قـرون شـهدت خلالها فترات من القوة والإزدهار تمتع فيها الخلفاء بكل مظاهر الترف والعظمة والأبهة، وفترات من الضعف والتدهور والإنكسار ؛ ذاق فيها الخلفاء كل مظاهرالعذاب والبؤس والهوان إلى أن سقطت هذه والإنساء

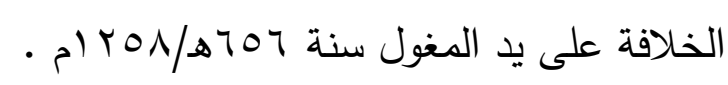
ويقدم هذا البحث تفسيراً ورأيـاً جديداً حـول الملابسـات والأسـباب التـى أدت إلى وفـاة وربمـا مقتل الخليفة المهدى- ثالث الخلفاء العباسيينمن خلال دراسة لدرهمين نادرين ينشران لأول مرة فى هذا البحث(')ولشك أن النقود هي مرآة صادقة تعكس جميع ظروف وأحوال الدولة سواء السياسية

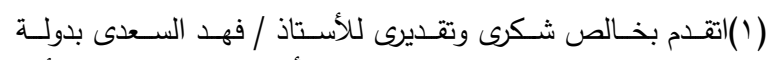
الإمارات العربية المتحدة الثقيقة الذى أهدانى صورة للفئل الدرهم الأول

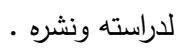

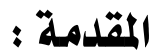

قامت الدولـة العباسية على انقاض الدولـة

الأمويـة فى سـنة ب إهـ/9 § Vم، وهـى دولـة

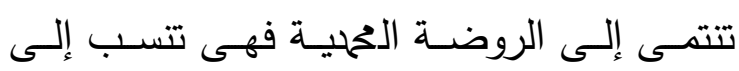

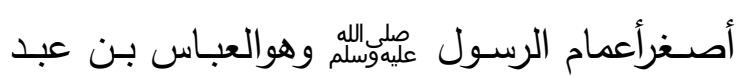

المطلب، ولم تكن قيام دولـة الخلافـة العباسـية

مجرد بيعـة خليفة دون آخر أوانتقال الحكم من

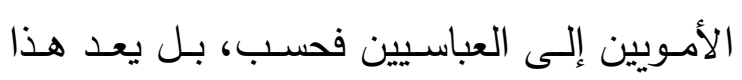

الأمرنقطـة تحـول عظيمـة فـى الدولـة الإسـلامية

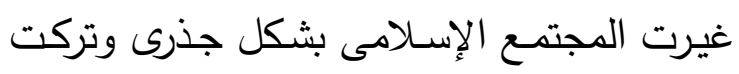
انطباعًا عميقًا فى جميع مناحى الحياة السياسية

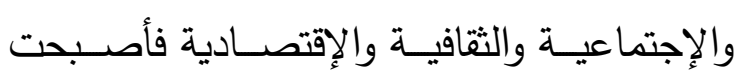

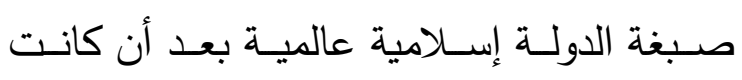
عربية وذلك بتفاعل عناصرمتعددة منها الفارسية والتركية،بإلاضـافة إلى العنصـرالعربي، واستمرت 


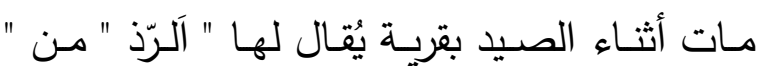
ماسبـذان" وقبـر هنـاك ("حيـث كـان يطـارد ظبيـاً فدخل الظبى إلى باب خربة فدخل فرس المهدى خلفه فدقه باب الخربة فقطع ظهره، وقيل أنه مات

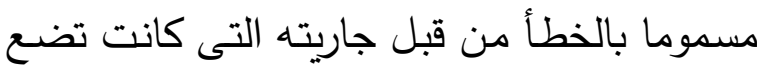
السم فى الطعام لجاريـة أخرى كانت الأولى تغار

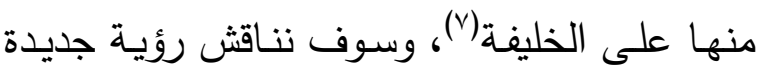
حـول وفـاة الخليفــة المهدى وعلاقــة هـذا الأمـر بالدرهين موضوع البحث . وصف الثكل العام للارهم الأول:

يتميزالثــكل العـام لهـــا الـــرهم بوجــود

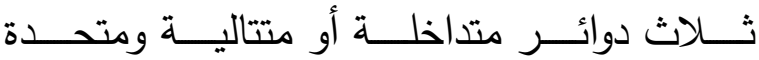

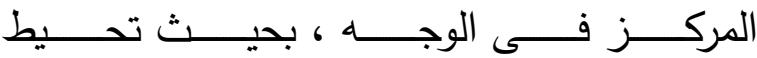
الـــــائرتان الخطيتـــــان الـــــاخليتان بكتابـــــات

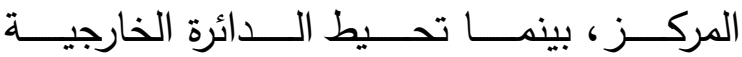

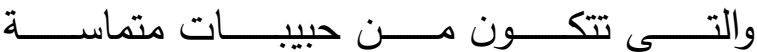

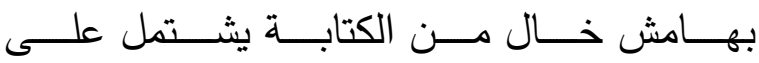

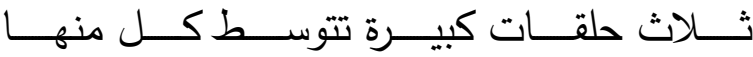

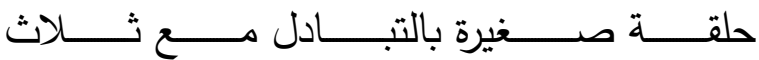
حلقات صغيرة على مسافات متساوية. أما الظهر : فيتميز بوجود ثلاث دوائر خطية متداخلة ومتحدة المركز تحيط الدائرتان الداخليتان

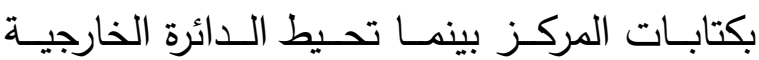
بكتابـات الهـامش مـن الخــارج. وجـاء مضــمون كتابات هذا الدرهم كما يلى:(لوحة وشكل ا )

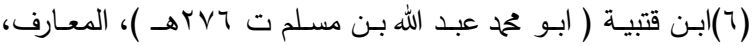

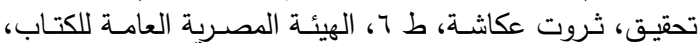

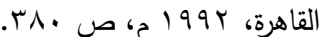

أوالإقتصــادية أوالإجتماعيــة أوالدينيــة ولـــللك

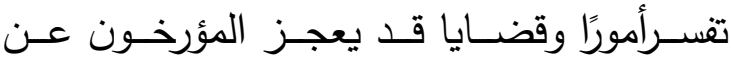
تفسيرهاومن هنا تأتى أهيتها وإن جاز التعبير فهى أصدق قولًا من أراء المؤرخين أحياناً لأنها تثبت هذه الأراء أوتتفيها أوتُقنَدها.

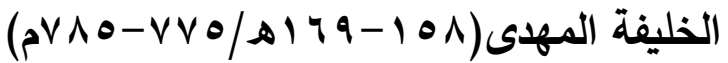
هـو مححد بـن عبــ الله المنصـوروهو ثالـث الخلفاء العباسيين، وأمها أروى بنت منصور عبد الهد

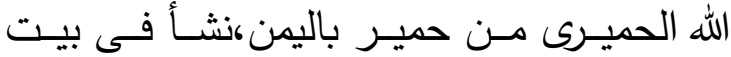
الخلافة وقد عنى أبوه المنصور بتثقيفه (r)، وقد بويع لـه بالخلافة يوم وفاة أبيه بعهد منه وهو البها

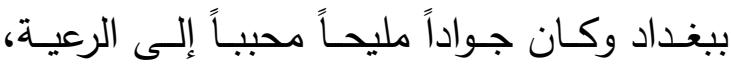
حسن الخلقة والخُلق (ז)، وتعتبر فترة حكمه انتقال بين عهد الثدة والقهح الذى ساد عهد من سبقه من خلفـاء بنى العباس وعهد الاعتدال واللين الذى امتازت به أيامه وأيام من بعده(؛)، وكانت الأت وفاة الخليفة المهدى فى المحرم لثمان بقين منهـ

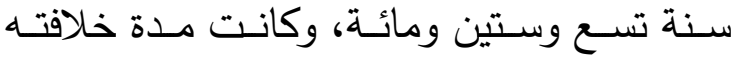
عشرسنين وشهرا، وتوفى وهو ابن ثلاث وأربعين

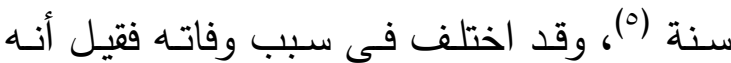

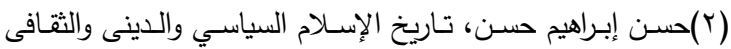

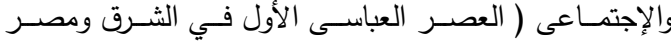

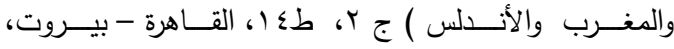

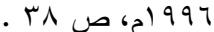

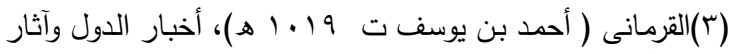

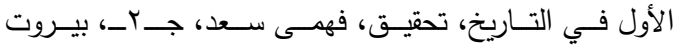

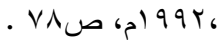

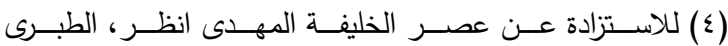

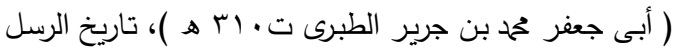

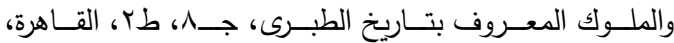
.

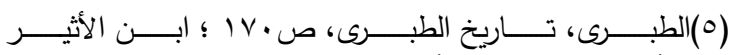

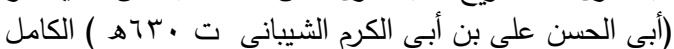

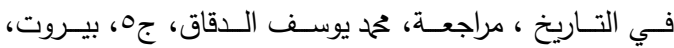




\begin{tabular}{|c|c|}
\hline 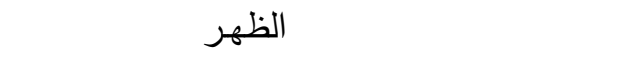 & 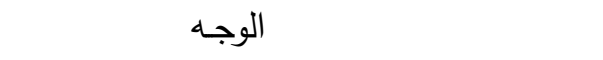 \\
\hline 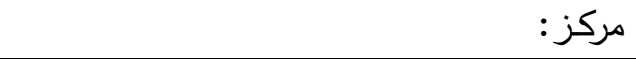 & 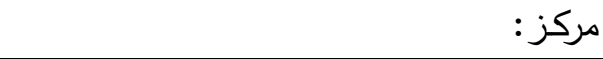 \\
\hline حمح رسول الله & ل ل إله إلا \\
\hline 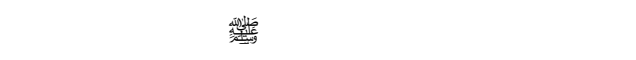 & الله وحده \\
\hline الخليفة المهدى & لا شريك له \\
\hline$\tau$ & هامش داخلى: \\
\hline هامش: & بسم الله ضرب هذا الدرهم \\
\hline محهد رسول الله أرسله بالهدى ودين & بالبصرة سنة تسع وستين ومئة \\
\hline الحق ليظهره على الدين & 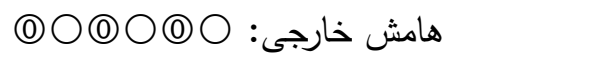 \\
\hline كله ولو كره المشركون. & \\
\hline
\end{tabular}

غير كاملـة، ونصـها " بسم الله" ، ومـن المعروف

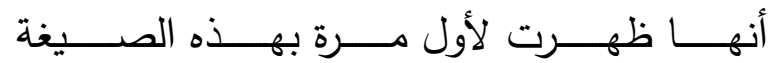

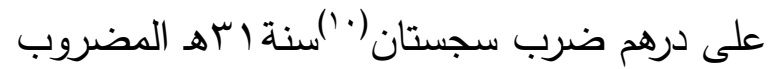
على الطـراز العربـى الساسـانى وكانــت مسـجله

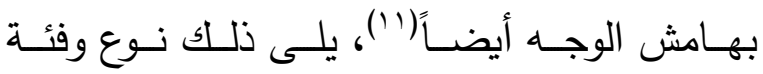
النقد، ثم اسـم مكـان وتـاريخ السـك وهـو البصـرة ســنة 79 اهـ بصـــيخة "ضــرب هـــا الــدرهم بالبصـرة ســـة تسـع وسـتين ومـــة"، ويلاحـظ أن مكان السك والتاريخ هنا يعتبر الاصدار الأخير مـن الـدراهم الفضـية لـدار ضـرب البصـرة فـى

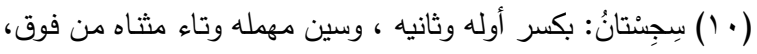

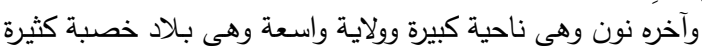

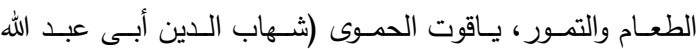

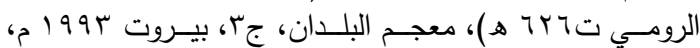

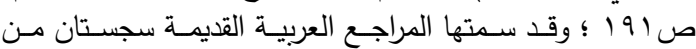

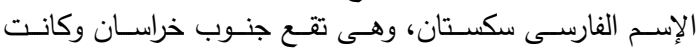

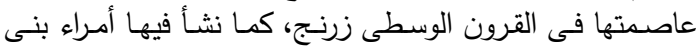

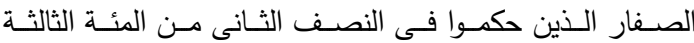

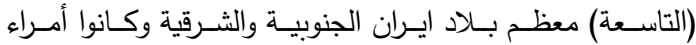

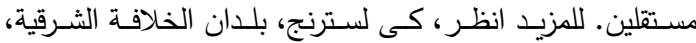

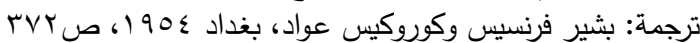

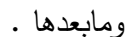

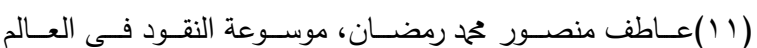

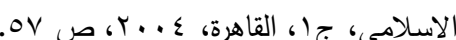

تتكـون كتابـات مركـز وجـه هــذا الطـراز من ثلاثة أسطر متتالية بالخط الكوفى البسيط تشـتمل على شـــادة التوحيـد كاملـة ونصــها:" لا إلــه إلا /الله وحــده/لا شــريك لــه "، وهـى تمثـل الـركن الأول فـى العقيـدة الإســلامية ولا

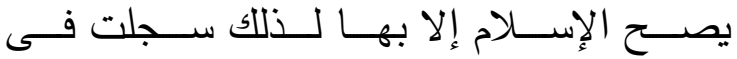

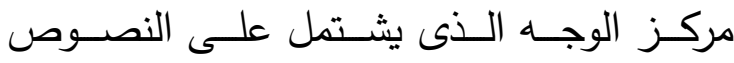

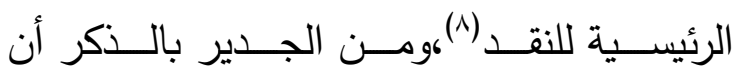
شـهادة التوحيـد نقشــت لأول مـرة بهـذا الترتيـب بعد تعريب النقود فى عهد الخليفة عبد الملك

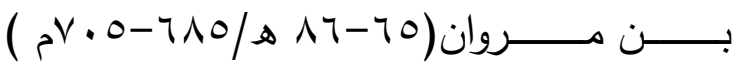
على الدنانير ثم الدراهم(9). أمـا هـامش الوجـه الـداخلى فكتاباتـه تسـير عكس عقـارب السـاعة وتثـتمل على البسـملة

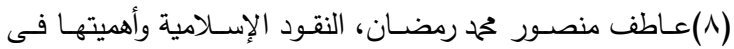

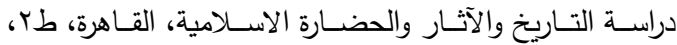
נו.

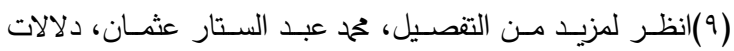

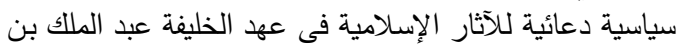

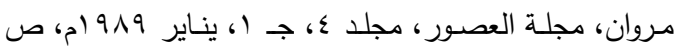
ص مر 


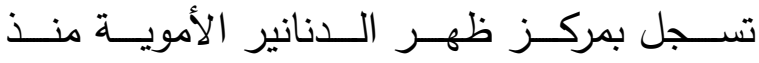

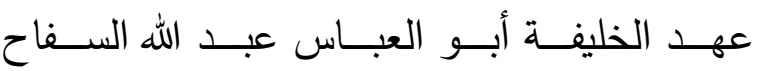
( تعتبـر مسن العبـارات والمبــادئ التـى رفعهــا

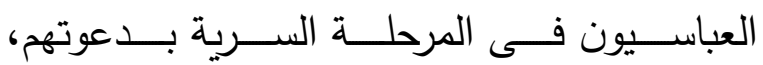

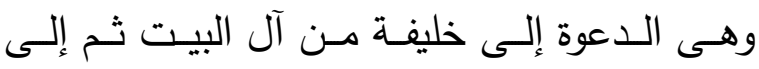
خليفـة مـن آل محمد ثم إلى خليفـة مـن العباسيين

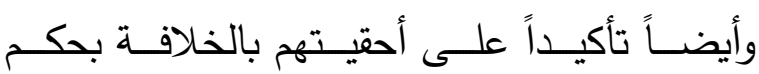

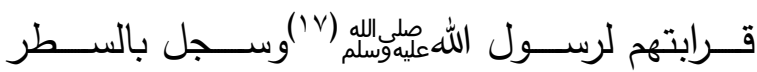
الثـانى عبــارة التصـلية علــى الرســول الكـريم صـلوات الله عليـه، وقــ ظهـرت عبـارة التصـلية

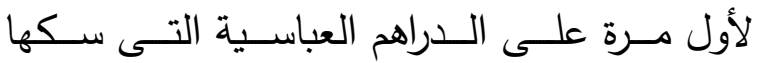
الخليفة المهدى، وذلك منذ الأيام الأولى لخلافته

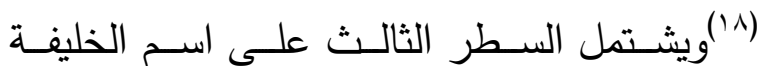

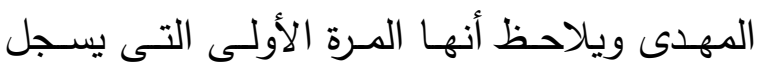
فيهـــا اســـم الخليفــة علــى الـــراهم العربيـــة الإسلامية(19).

ويلى ذللك فى السطر الرابع حرف الحاء" ح حسبه

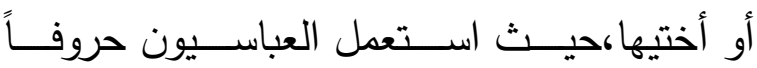
هجائيـة كثيرة متقطعـة ومسن المحتمل أن يكون

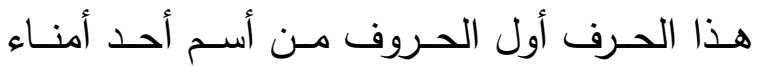

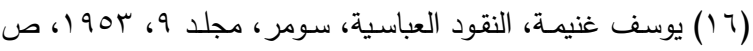

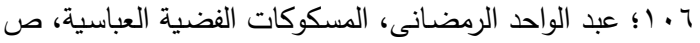

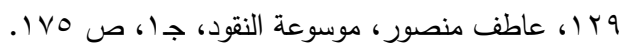

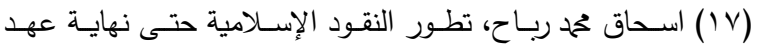

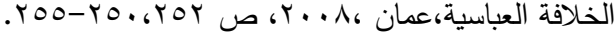

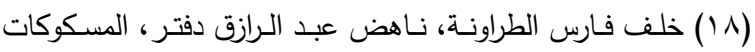

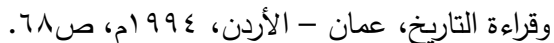

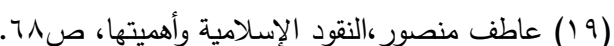

عهد الخليفة المهدى العباسى لأنسه توفى فى (النى

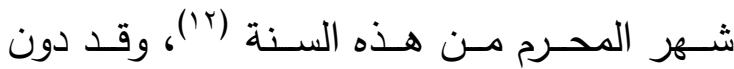
التاريخ الهجرى هنا بالحروف العربية، ويعتبرهذا

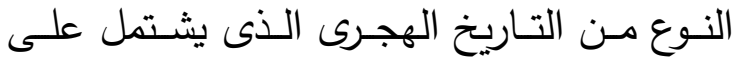
ســة الضـرب فقــ الأقـدم فـى الظهـوروالأكثر

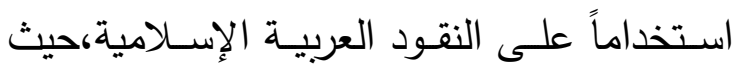

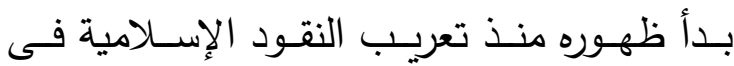
عهد الخليفة الأموى عبد الملك بن مروان وظل مسـتخدماً على النقـود الإسـلامية حتى القـرن

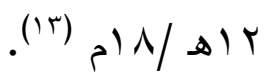

أهـا الهـامش الخــارجى للوجـهـ فهـو خـال من الكتابة ويشتمل على مجموعة من الحلقات

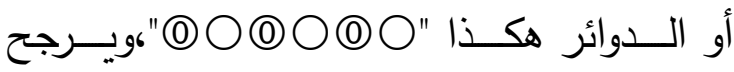
بعض الباحثين أن هذه الحلقات أوالدوائر عبارة عن زخارف هندسية(؛ (1) وبالنسـبة لمركز الظهر فهـو يتكـون مـن أربعة أسطر متتالية بالخط الكوفى البسيط، سجل

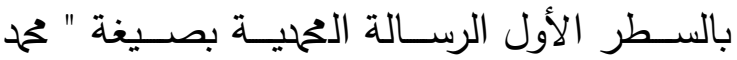

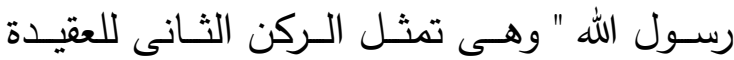

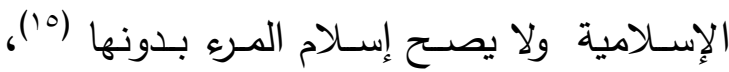

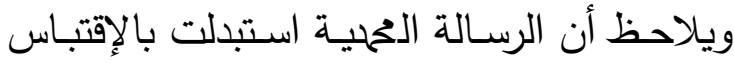

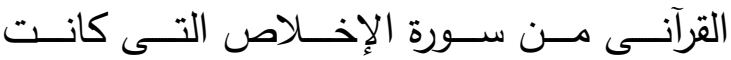

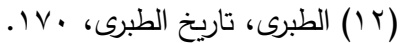

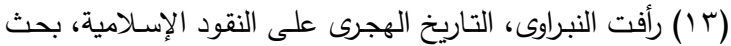

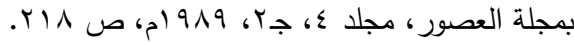

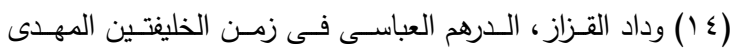

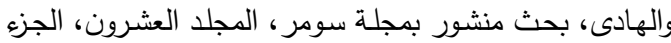

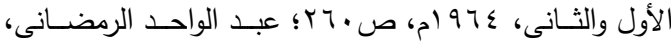

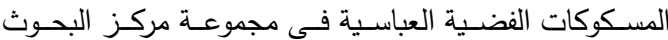

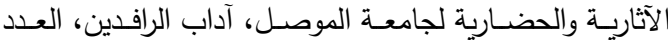

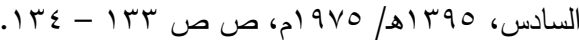

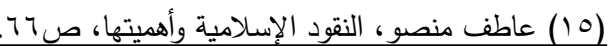




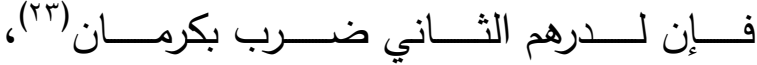

وهـــو الإصـــدار الأخيـر أيضًَــا مــن الــــراهم

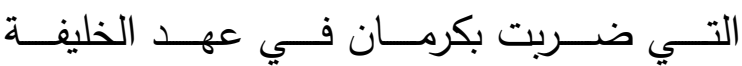

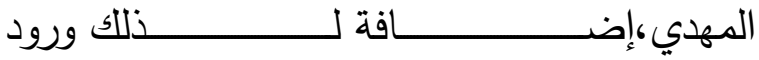

كلمـة بــخ (r)أســفل كتابـات مركـز الظهـر لــــا

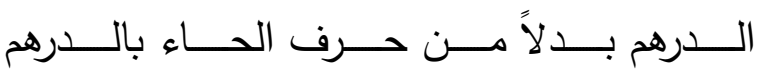

(rT) كرمان:اطلق اسم كرمـان من قديم على ولاية كرمان الإيرانية

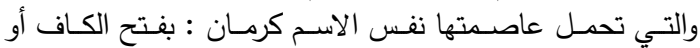

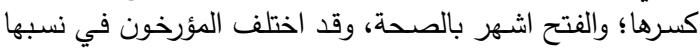

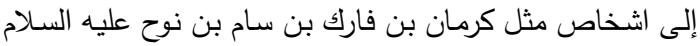

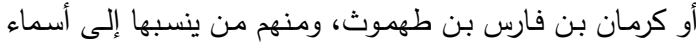

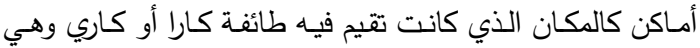

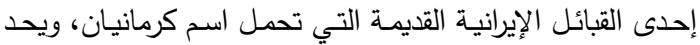

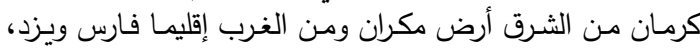

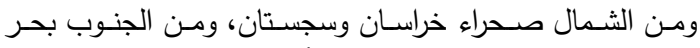

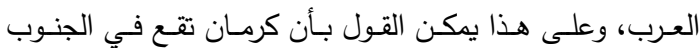

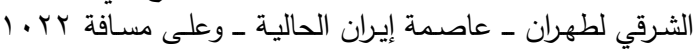

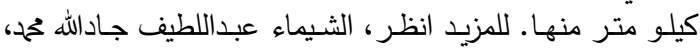

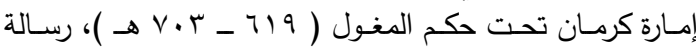

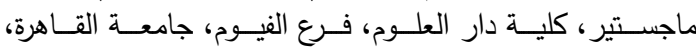

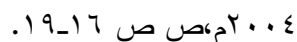

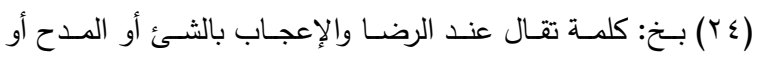

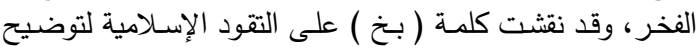

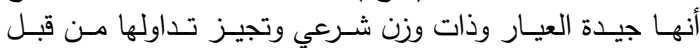

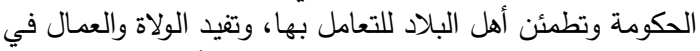

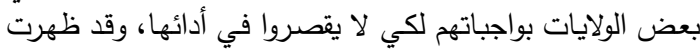

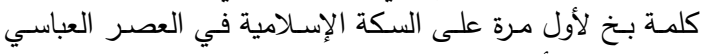

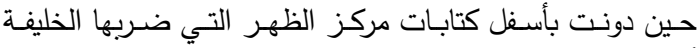

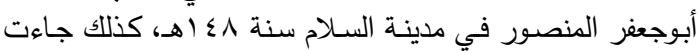

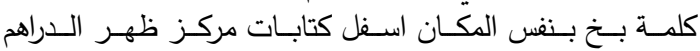

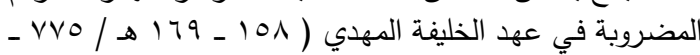

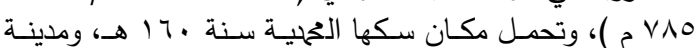

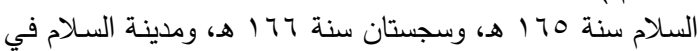

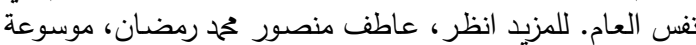

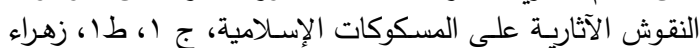

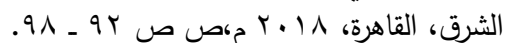

دور الضــرب أو وكلائهــا أو أصــحاب العيــار فيها والطباعين والضرابين (·r) . أمـا هـامش الظهـر فقـــ ورد بـهـ الإقتبـاس القرآنـى مـن سـورتى الفـتح آيـهـ رقـم وب " محمد رسـول الله " وسـورة التوبـة آيـة رقم سب " أرسـله بالهدى ودين الحق ليظهره على الدين كله ولو كره المشركون "، وتم استبدال قولـه تعـالى "هو الـــى أرسـل رســوله " بوضــع اســم الرســول

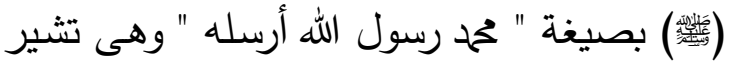

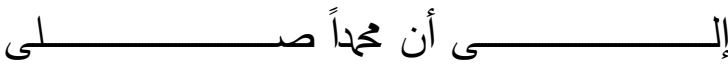
الله عليـه وسـلم هـو خـاتم الأنبيـاء والمرسـلين وصـــاحب الــدين الحـــق الــــى أظهــــره الله على سائر الأديان والمعتقدات ولو كره المشركون

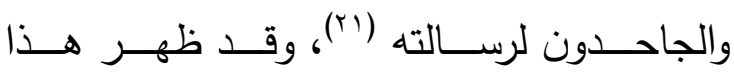
الإقتبـاس على الـدراهم منـذ تعربيهـا فـى سـنة (r) $(r) \wedge$

\section{وصف الثكل العام للدرهم الثانى :}

يتثــابه هــذا الــدرهم مــع الــدرهم الأول

فى الشكل العـام ومضـمون الكتابـات والزخـارف

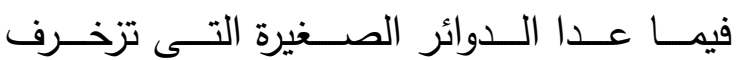

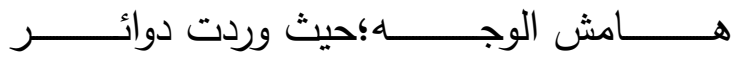

صــغيرة مفرغــة دون النقــاط الموجــوده داخـلـ الدوائر الصغيرة التى تزين هامش الدرهم الأول، وإذا كــان الــدرهم الأول قــد ضــرب بالبصــرة

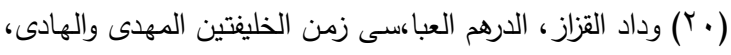

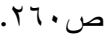

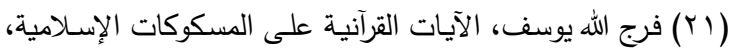

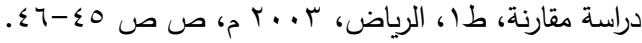

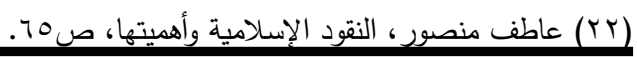


وجاء مضون كتابات هذا الدرهم على النحو التالى: (لوحة وشكل r).

\begin{tabular}{|c|c|}
\hline 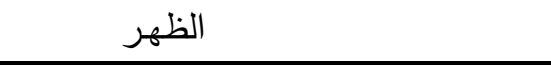 & 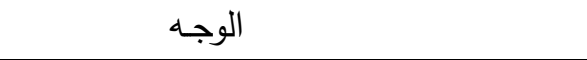 \\
\hline 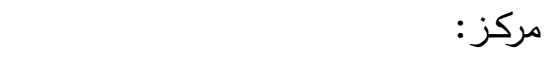 & 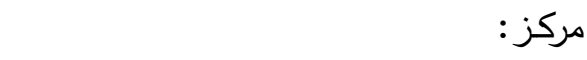 \\
\hline محمد رسول الله & لا إله إلا \\
\hline 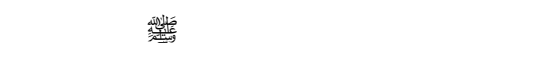 & الله وحده \\
\hline 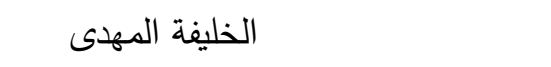 & لا شريك له \\
\hline بخ & هامش داخلى: بسم الله ضرب هذا الدرهم \\
\hline هامش: محمد رسول الله أرسله بالهدى ودين & بكرمان سنة تسع وستين ومئة \\
\hline الحق ليظهره على الدين & هامش خارجى: 000000 \\
\hline كله ولو كره المشركون. & \\
\hline
\end{tabular}

موسـى ولقبـهـ بالهـادى ومـن بعـده إبنـه هـارون

ومن خلال دراسة هذين الدرهمين ـ موضوع

الرشـيد فقـام بتسـجيل أسـم ولديـه موسـى الهـادى

البحث ـ والدراسات السابقة يتضـح لنا أن الخليفة

وهــارون الرشـيد علـى الـدراهم بإعتبارهمـا وليـا

المهـدى قـد أحسدث تغييـراً هامـاً علىى الـدراهم

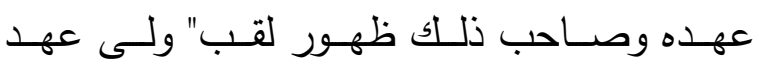

الفضـية وذللك منـذ بدايـة حكمـهـ فقـد أمسربنقش

المسـلمين" لأول مــرة علــى النقـود الإســلامية

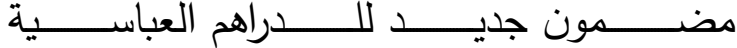

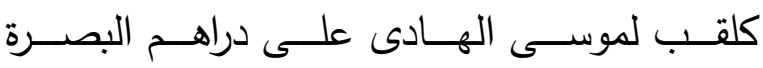

عندما أمر بإضـافة عبارة التصلية على الرسول

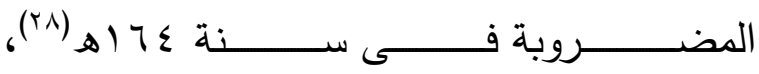

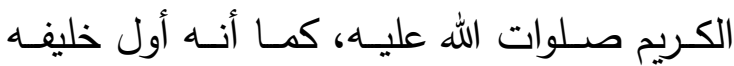

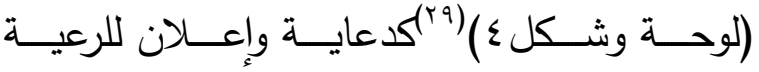

يقـوم بتسـجيل اسـمهه ولقبـهـ علـى الـدراهم(ro)

مسن المسـلمين بـأن مـن يعتلـى عـرش الخلافـة

$$
\text { (لوحة وشكل r)(rT) }
$$

من بعده هو إبنه موسى الهادى،

وحينمـا قـام الخليفـة المهدى بعزل عيسى

بـن موسـى(YV)، مسن ولايـة العهد وجعلهـا لإبنـهـ

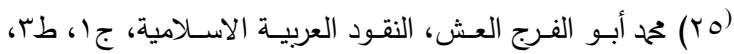

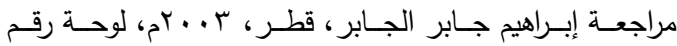

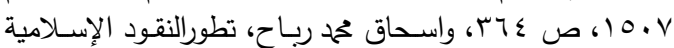

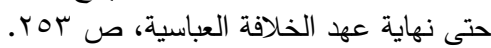

الخليفة أبو جعفر المنصور أراد أبوه أن يقدمه في ولاية العهد

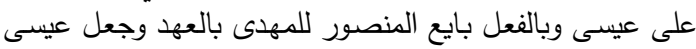

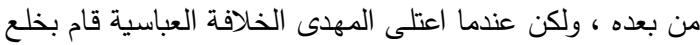

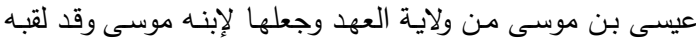

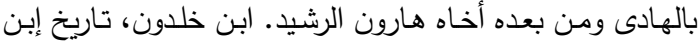

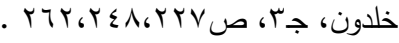

(28)Richrd Kimber:The Succession to the Caliph Musa al -, Journal of American Oriental

Society, vol.121 No.3, 2001,p 430 .

(29) Zeno : No, 41740.

Lane-poole :Catalouge of Oriental Coins in the British Museum vol.1, London,1875, No.95 .

A.ShamsEshragh: Sihver Coinage Of the Calphs,executed by Estack Press, Second edition ,2010,P.171, No.926

(26)www.Zeno.ru , No,161186.

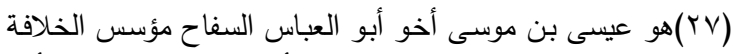

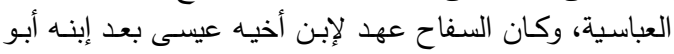


وجاء مضمون كتابات هذا الدرهم كما يلى:

\begin{tabular}{|c|c|}
\hline 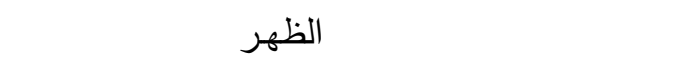 & 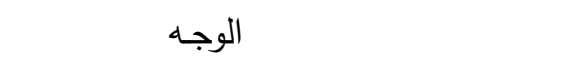 \\
\hline مركز : & مركز : \\
\hline الخليفة المهدى & لا إله إلا \\
\hline مما أمر به & الله وحده \\
\hline 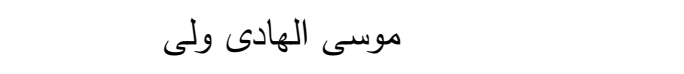 & ل ل الريك له \\
\hline عهز المسلمين & \\
\hline ص & هامش داخلى: بسم الله ضرب هذا الدرهم \\
\hline هامش داخلى: محم رسول الله أرسله بالهدى ودين & بالبصرة سنةأربع وستين ومئة \\
\hline الحق ليظهره على الدين & \\
\hline 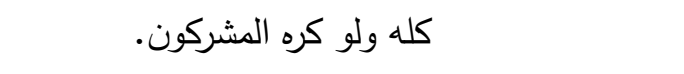 & 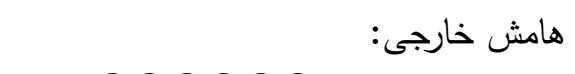 \\
\hline 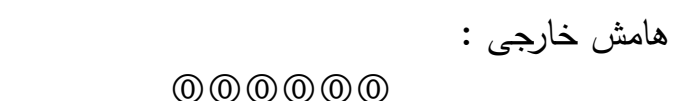 & (ㅇ) (1) (1) (1) (1) () \\
\hline
\end{tabular}

مـن لقب ولـى عهد المسلمين، إضـافة لــلكـ ومــن المعــروف أن الخليفــة المهـــى

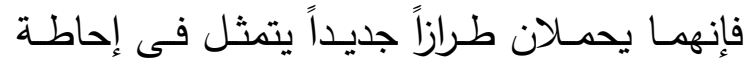

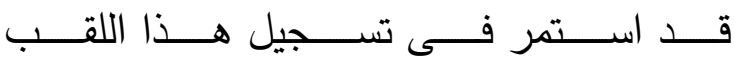
كتابات مركز الوجه بدائرتين فقط بدلاً من ثلاث

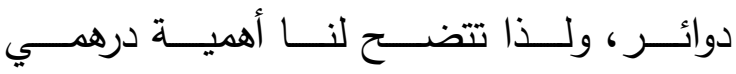
على دراهـم ضـرب البصـرة منـذ ســنة ؟ 7 اهـ (rr)

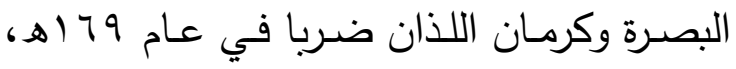

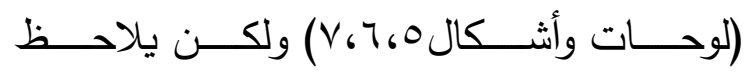

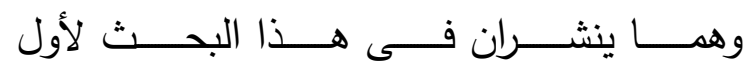

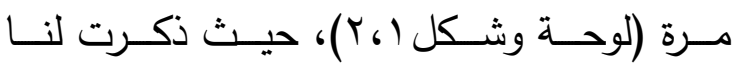

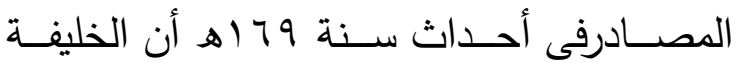
المهدى تغيرعلى ابنـه الهادى وقرر خلعـه مـن

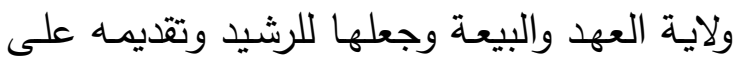

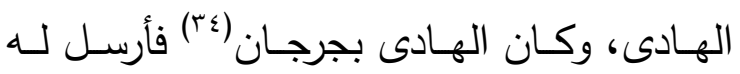
والـده يستقدمه ولكن امتـع الهـادى عن القدوم لأبيه وضرب الرسول فاستشـاط المهدى غضباً

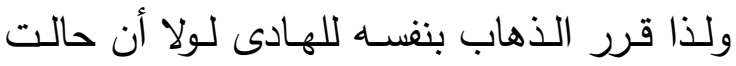

أن هـنين الـدرهمين- موضـوع البحث- خاليـان

(30)Lane Poole: Catalogue ,V.1,No98 - Nicholas Lowic: early Abbasid Coinage Atype Corpus (132-218 H -750-833AD),puplished by Britsh Museum, London ,1996 p.141,No.1037 .

(31)Lane Poole:Catalogue ,V.1,No99

A.ShamsEshragh: Silver Coinage of the Calphs, p. 174 , No.944 .

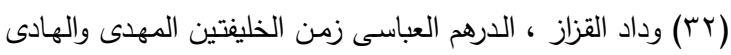

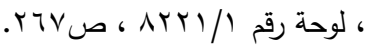

Norman d.Nicol Raafat El-nabrawy ,Jerel.bacharach:Catalog of the Islamic Coins Glass Welghts, Dies and Medals in the Egyptian National library Cairo 1982 ,p.19 ,no.777

Zeno : No, 123309

(33)Lane Poole : Catalogue ,V.1,No ,100 American Numismatic Society, No , 1917.215.227. 


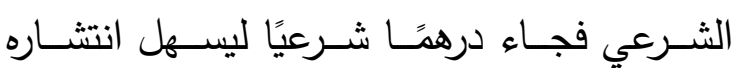
والإقبال عليه.

ويؤخـذ فـى الاعتبـار أن الخليفـة المهـدى

توفى فى شـر المحرم مـن هذه السـنة ويـرجح

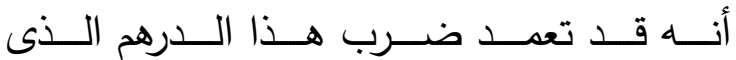
لا يشـتمل علـى اســم موســى الهــادى ولــى عهده ليعلن لرعاياه بأنه خلع الهادى، ولهذا فإن هذا الدرهم ـ درهم المهدي 99 اهـ - يؤكد لنـا مـا ذكرتـه المصـادرالتاريخية مـن تغيـر المهـى تجـاه ابنـه الهادى؛ويضيف لنا تصوراً آخر وهو أنه ربمـا يكون الهادى هو من أرسـل من يقتل والده حينما علم بهذا الأمر ، سيما وأن المصسادر لم تؤكد سببًا محدداً لوفاته حيث يذكر لنا ابن الاثير " وقد اختلف في سبب موتـه " لـذا فـان الأسباب التى ذكرتها لنا المصادر غير مؤكدة، وتشير لنا المصادر أنه بعد وفاة الخليفة المهدى كان الهادى بجرجـان يحارب أهل طبرستان (rv) أمسا هـارون الرشـيد فكـان معسه وعنـدما تـيقن الجنـد بمـوت المهـدى ثـاروا مطـالبين بـالأرزاق ثم سـاروا إلـى بغـداد فـى ثـورة غضـب وقـاموا بحرق بـاب "الربيعع" مولى الخليفـة المهدى وهنـا

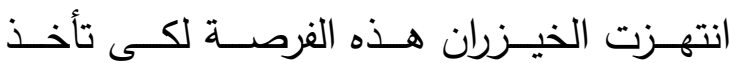

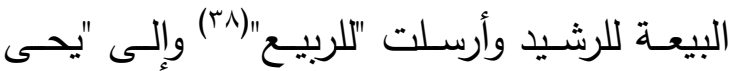

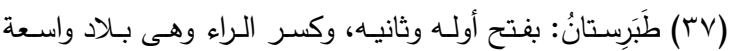

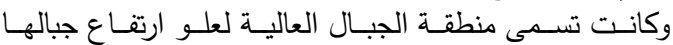

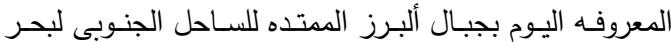

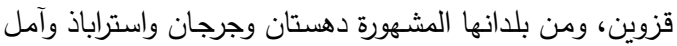

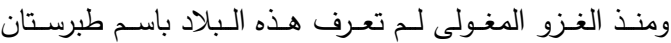

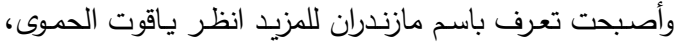

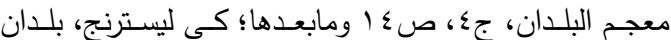

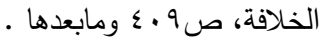
(r/N)

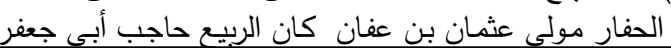

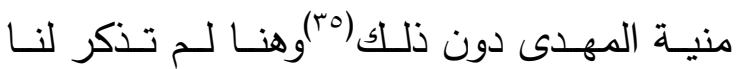
المصادر ماهو سبب تغير المهدى على الهادى ولكـن يُستشـف ممـا ذكرتـهـ المصـادر التاريخيـة

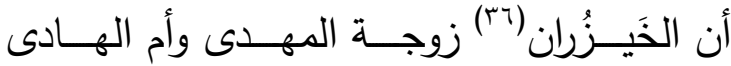
وهـــارون الرشــيد كانــت تميـلـل للرشــيد دون الهادى لغلظته معها، فربما كانت الخيزران سببًا فى تغير المهدى على ولده الهادى ممـا دفعـه لخلعه من ولاية العهد. يلاحـظ أن هـذين الـدرهمين - موضــوع

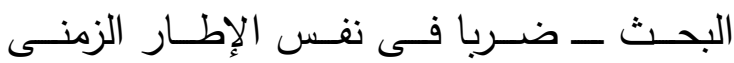
الذى ذكرت فيه المصـادر بأن الخليفـة المهدى تغيـر على ابنـه الهـادى حيـث أنهمـا يحمـلان تـاريخ 79 اهـ، ويبـدو أن المهـدي في مسـتهل هذا العـام قد أمـر بسرعة ضـرب الدرهم الجديد

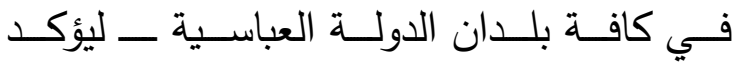
خلعـه للهادي - منها على سبيل المثال: درهم

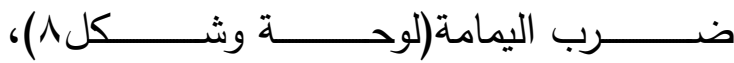
درهـم ضـرب قصـر السـلام (لوحسة وشـكله9)، "درهـم ضـرب إفريقيـة (لوحـة وشكل • ( )، درهـم

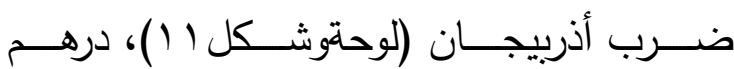
ضرب هارون آباد (لوحة وشكل r ())، ولكي يقبل الناس على هذا الدرهم فقد اهتم المهدي بوزنـه

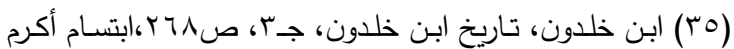

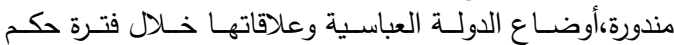

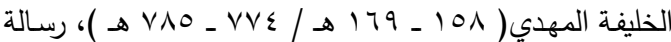

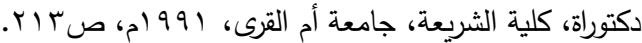

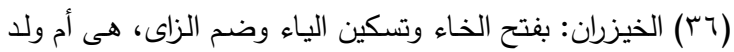

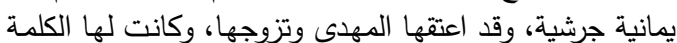

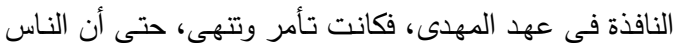

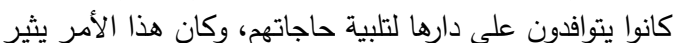

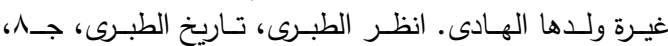




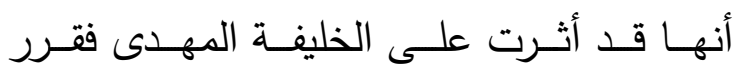

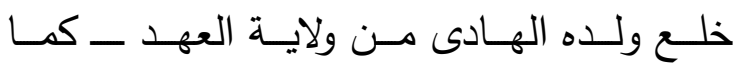
ذكرنـا آنفًا ــ فكـان ضـرب الـدرهم في مسـتهل

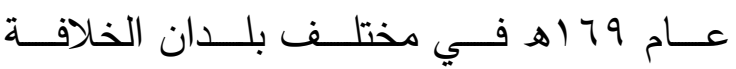
العباسـية دون اســم الهـادي إحـدى الخطــوات الرســية التهى تؤكـد ذلـلك، ويـرجح أن الهـادى قد أدرك خطورة هذا الأمر ولهذا قرر التخلص مـن والـده المهـدى، بـل ودفنـه في البلـدة التي مـات فيهـا ولـن يحمـل إلى بغـداد ليـدفن معــه

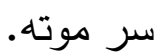
وإن صح هذا الترجيح فإننا يمكن أن نطلق على هذا الدرهم أنه الدرهم الذى قتل صاحبه .

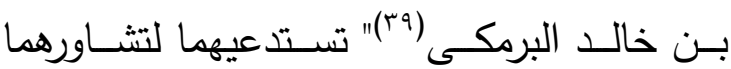
فى ذلك ، لكن امتتع يحىى لمـا يعلم مـن غيرة

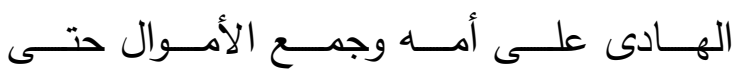

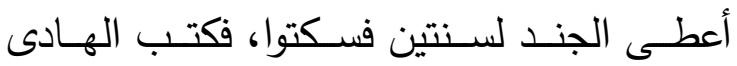
إلـى الربيــع يهـدده بالقتـل وكتـب إلــى يحسى يشكره، واستشـار الربيع يحى فيمـا يفعلـه فأشـار

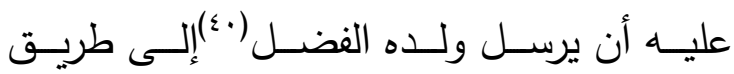

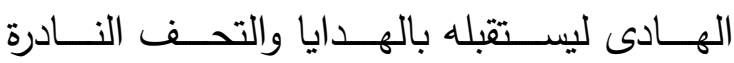
ففعل وأُخذت البيعة للهادى ببغداد (1).

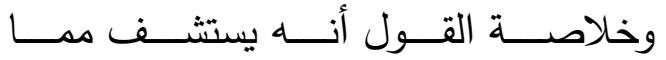
ذكـره المؤرخـون أن هنـاك جفـاءً بـين الهـادى

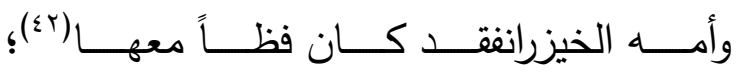

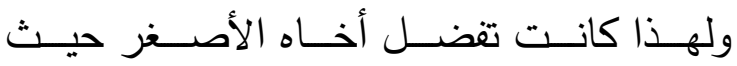
كانـت تتمنى أن يعتلى هـارون عـرش الخلافـة

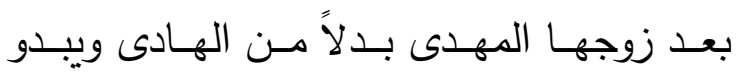

ومولاه ثم سار وزيره ثم حاجب المهدى وهو الذى بايع المهدى

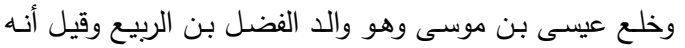

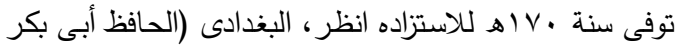

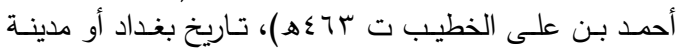

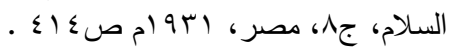

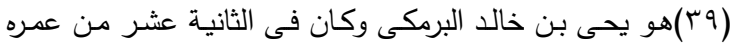

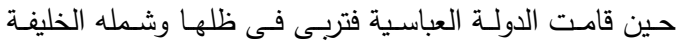

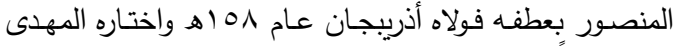

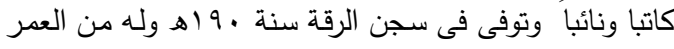

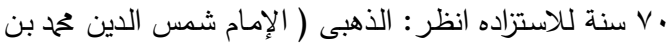

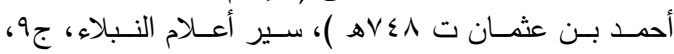

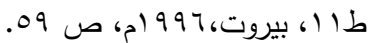

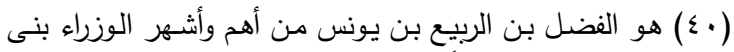

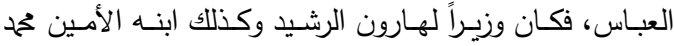

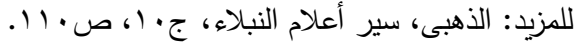

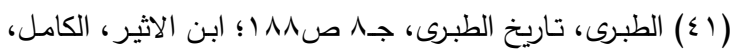

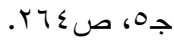

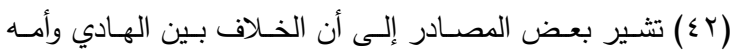

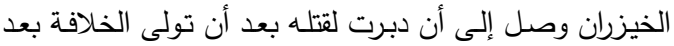

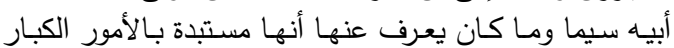

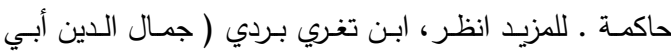

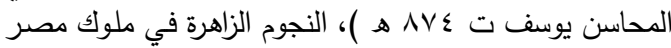

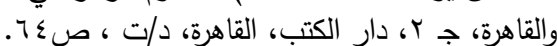


اللوحات والأثكار

لوحة رقم الوهال
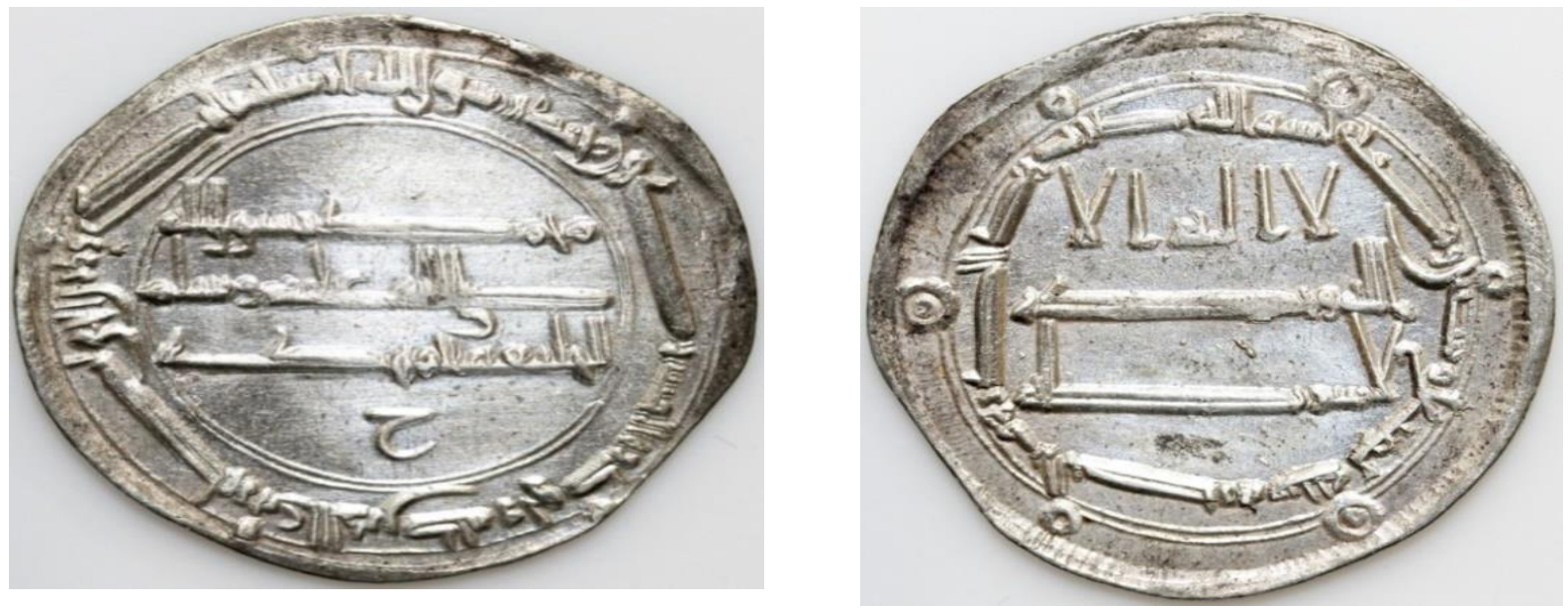

درهم باسم المهدي ضرب البصرة سنة 79 أه يبلخ وزنهو,r محفوظ بمجموعة الأستاذ فهد السعدى، ينشر لأول مرة. شكل رقم
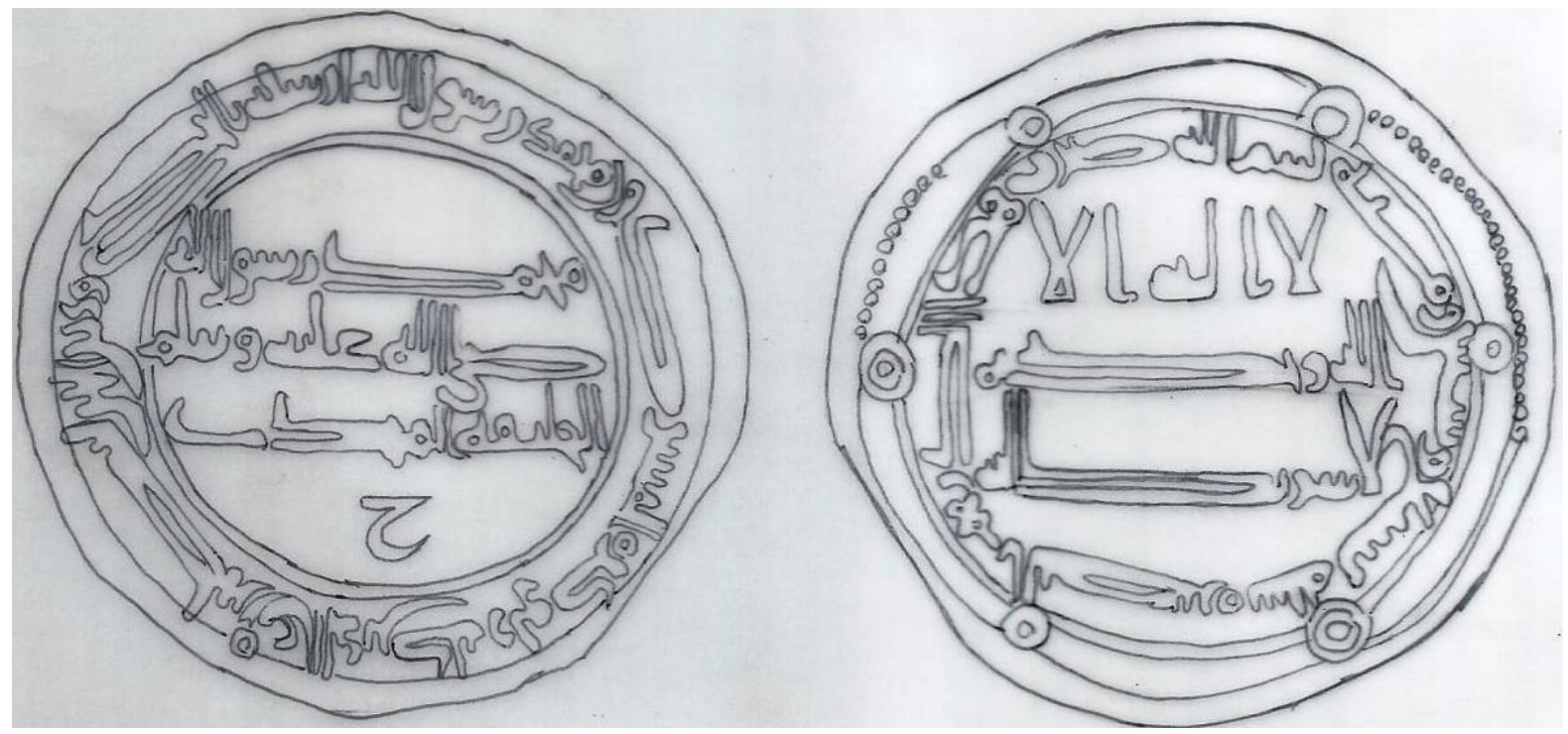

تفريغدرهم باسم المهدي ضرب البصرة سنة 79 اهـ يبلغ وزنهو, r محفوظ بمجموعة الأستاذ فهر السعدى . 

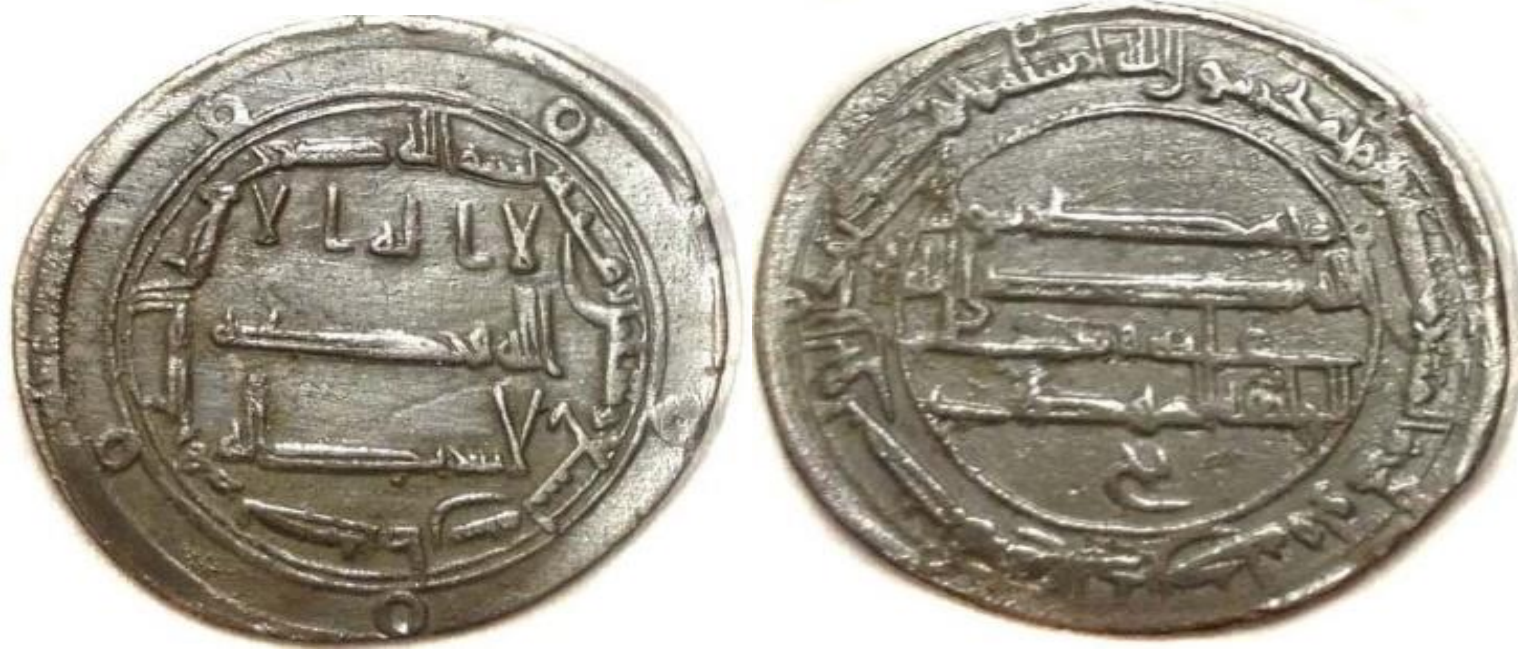

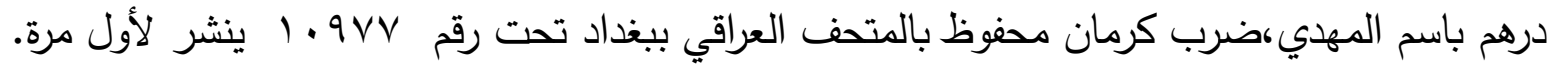
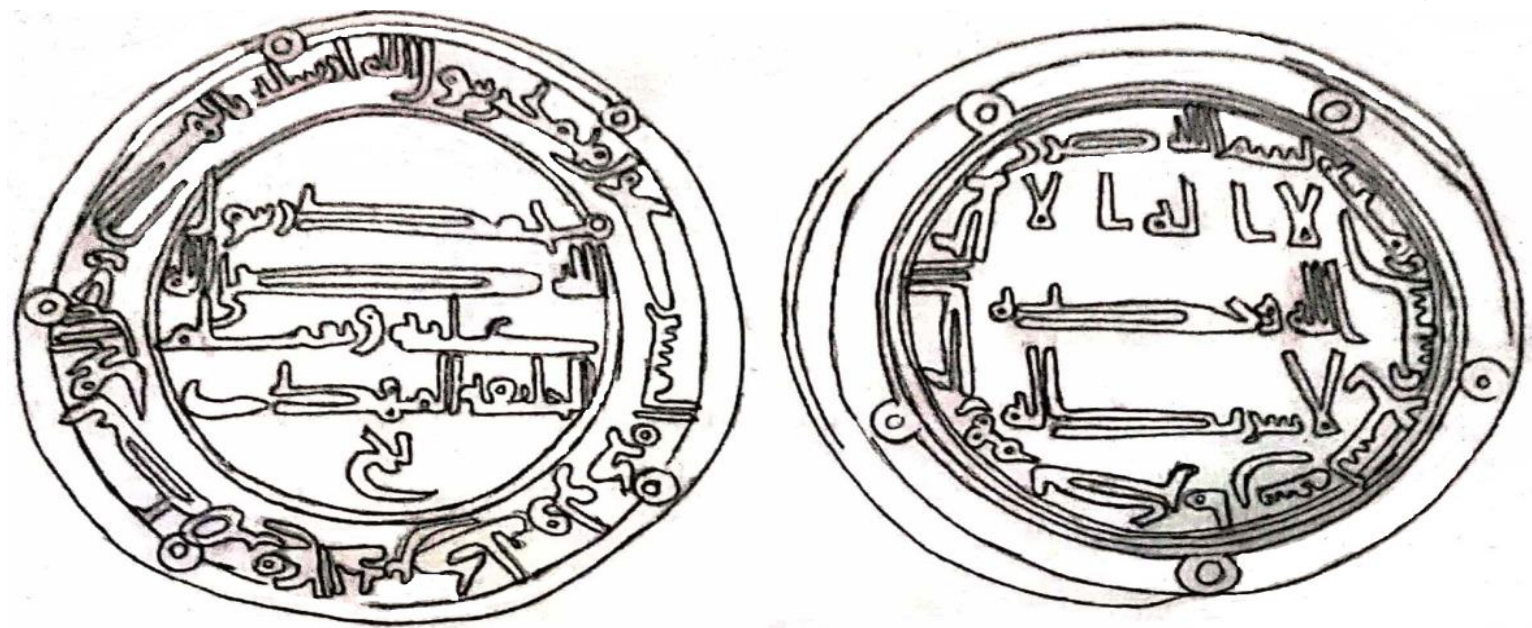

تقريخ درهم باسم المهذي ضرب كرمان محفوظ بالمتحف العراقي ببغداد تحت رقم 1 VVV ينشر لأول مرة. 

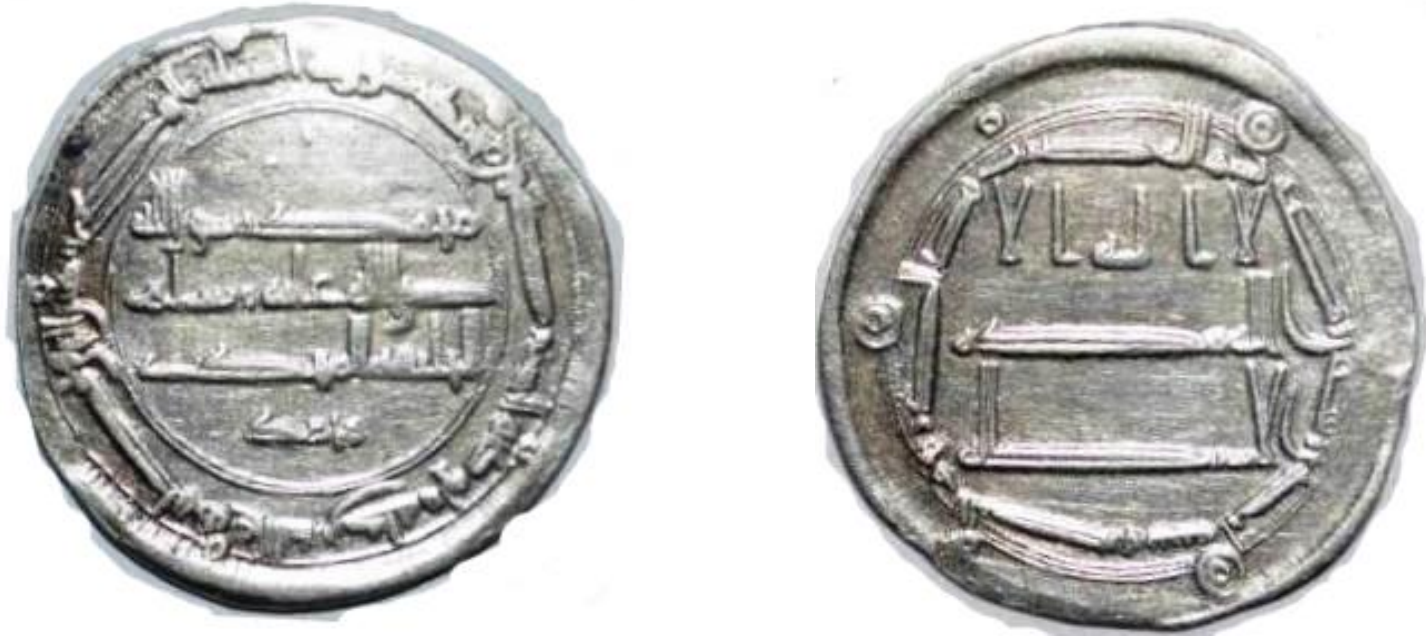

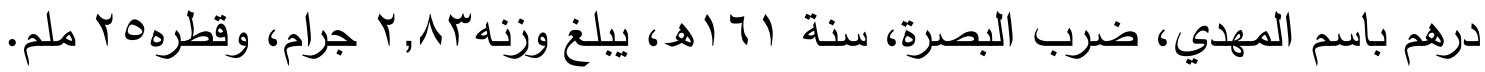
, No,161186www.Zeno.ru شكل رقم
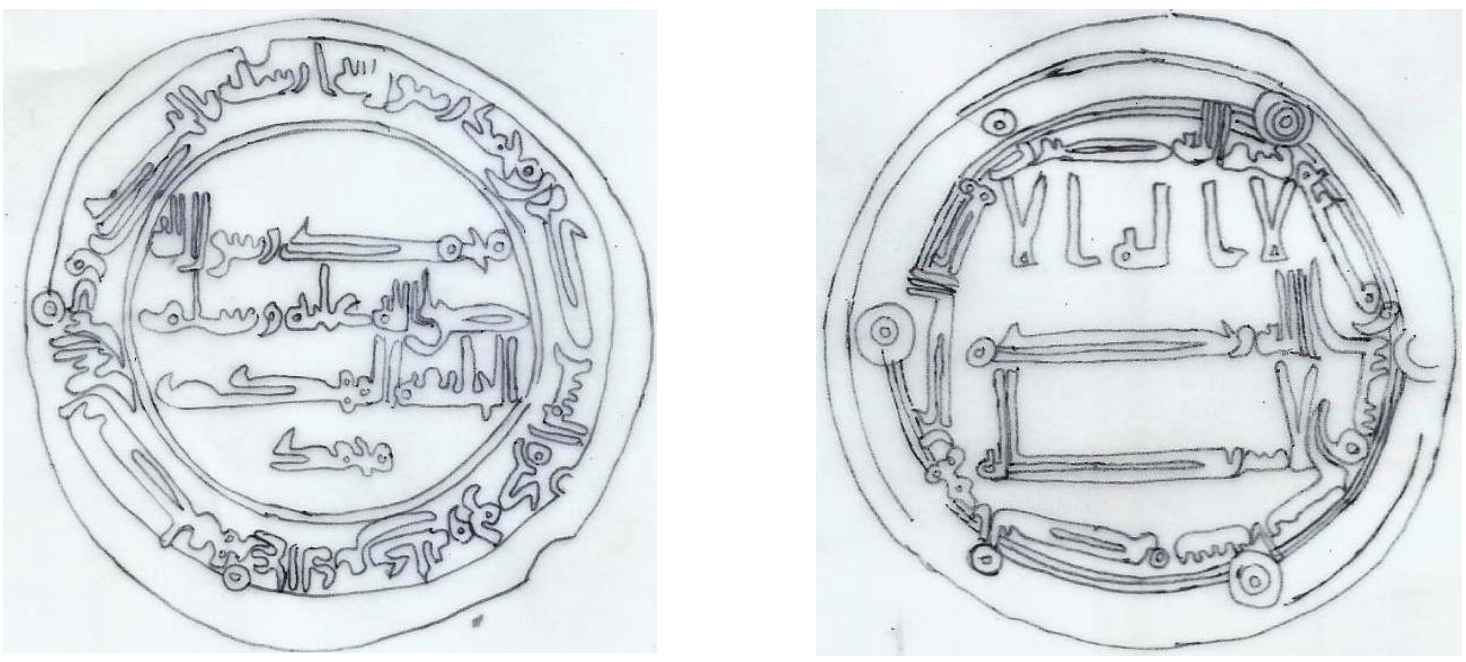

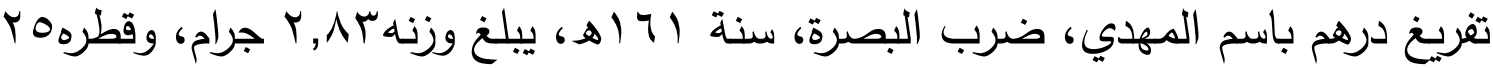

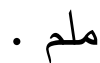



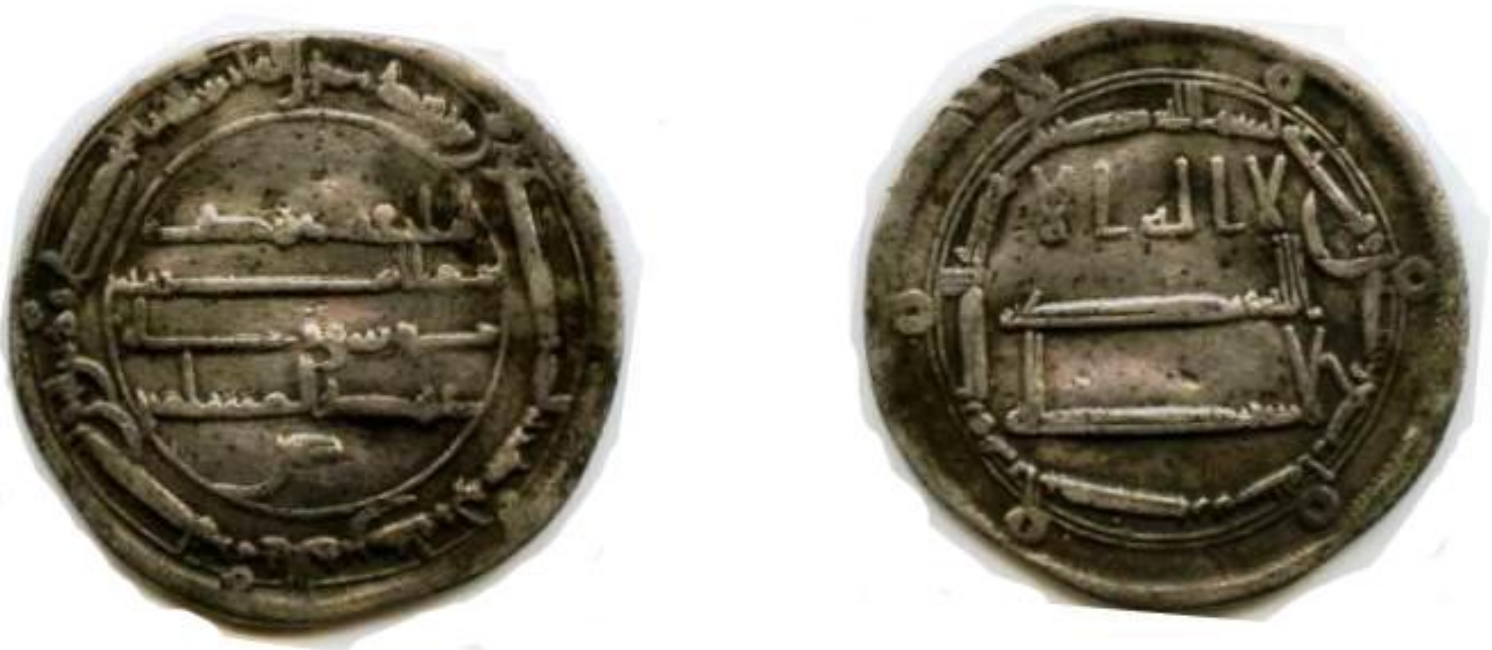

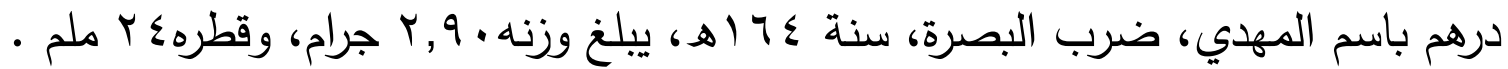
Zeno : no, 11740 .
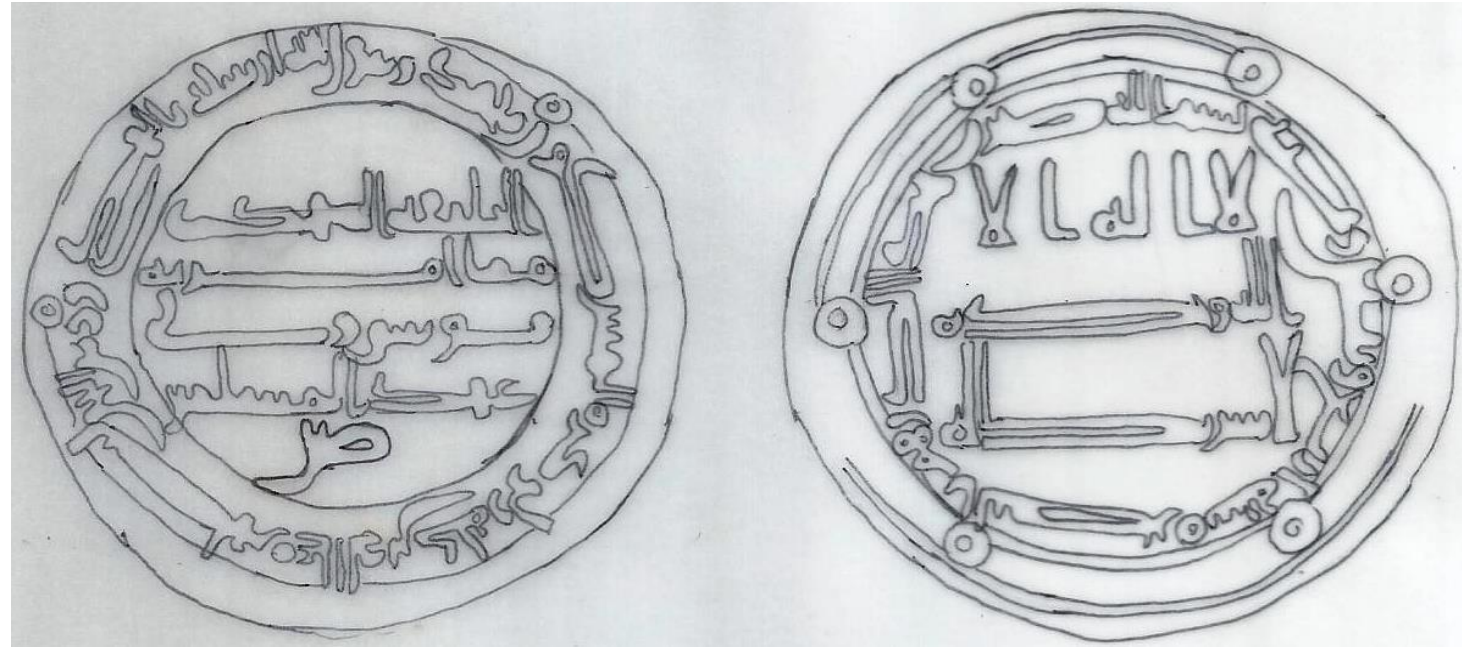

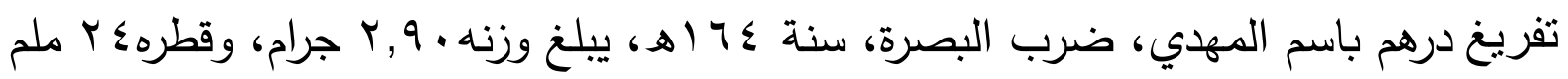


0 ثو
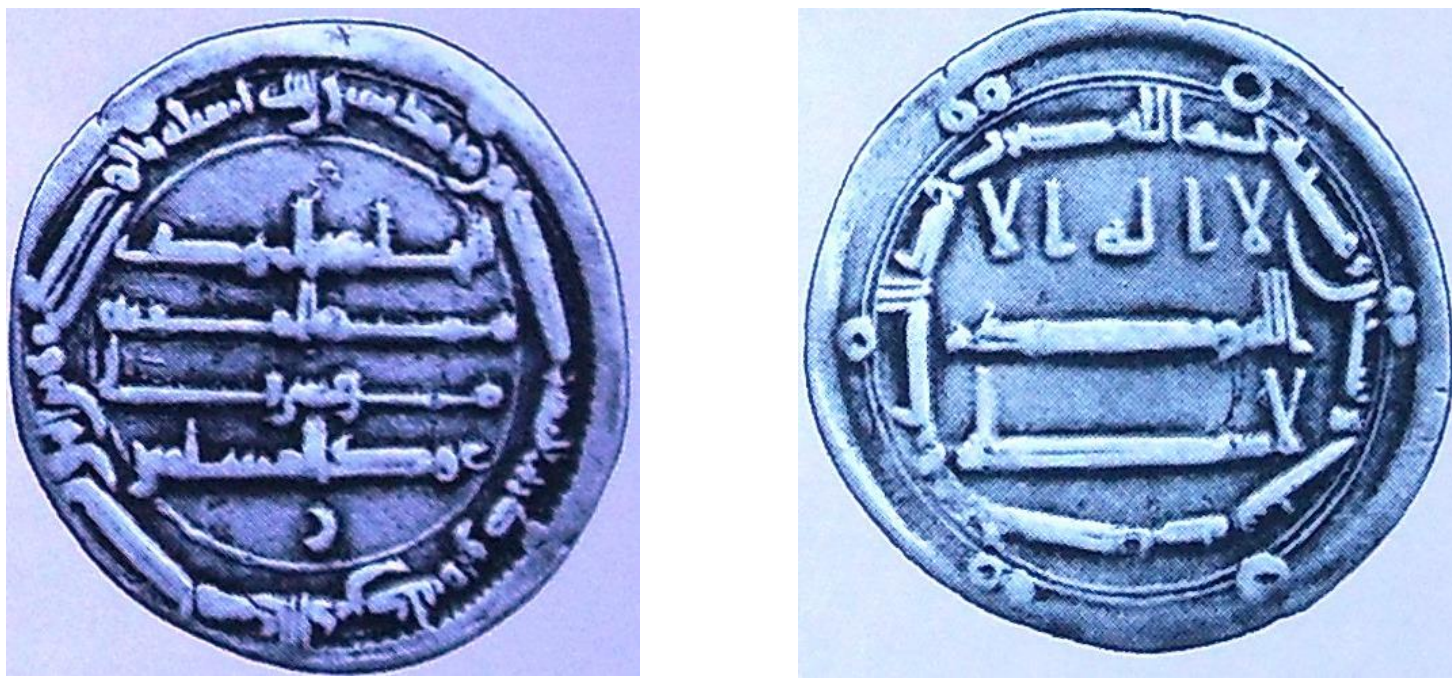

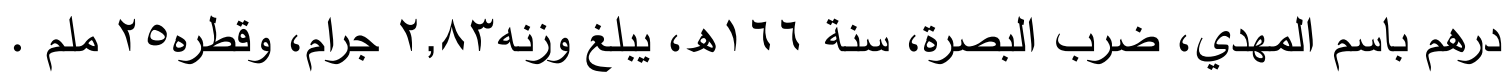

Shams Eshragh : p .174

شكل رق
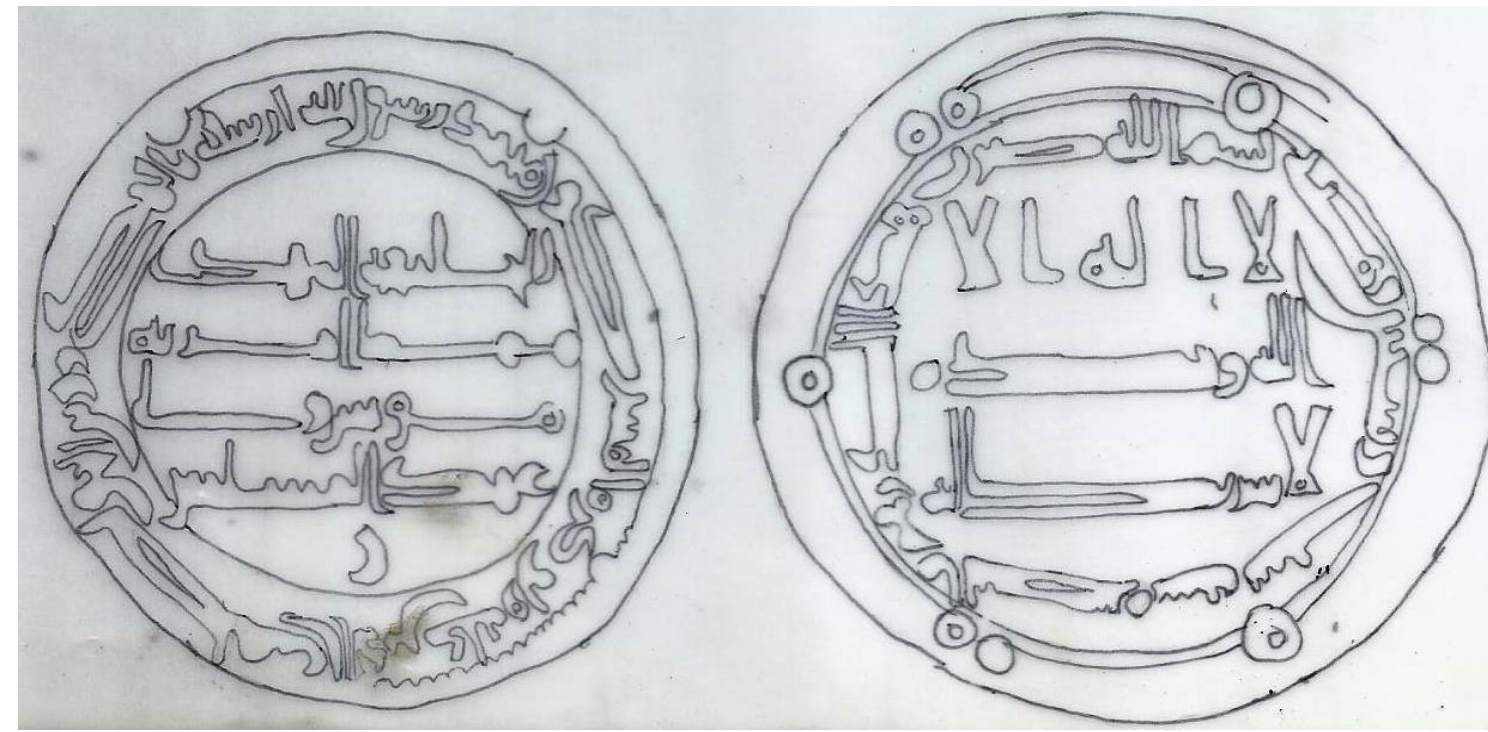

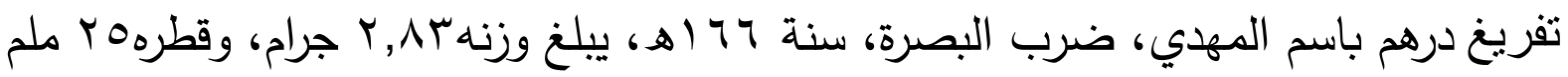



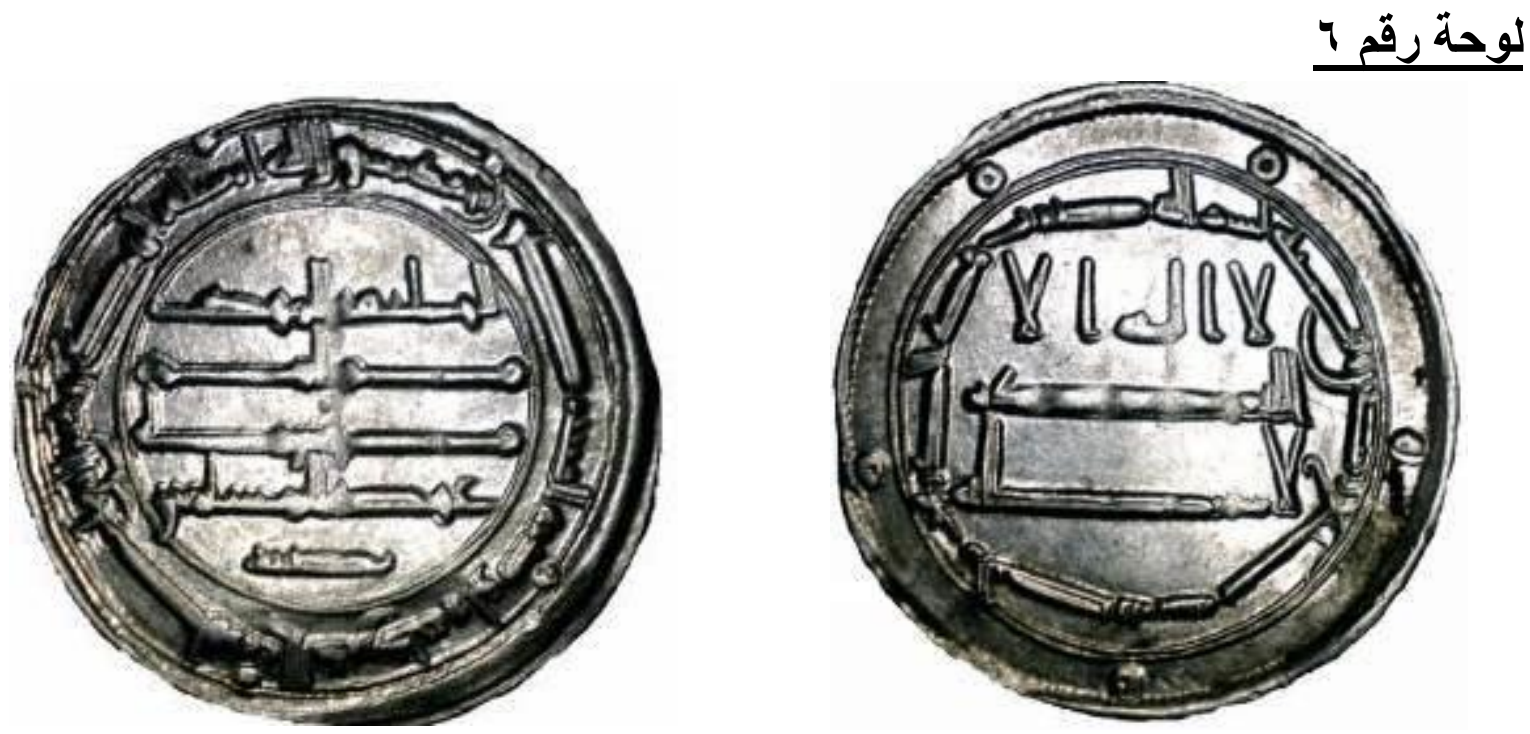

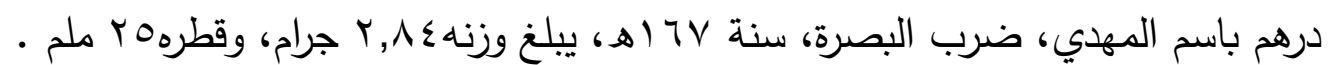
ZENO: NO, 123309
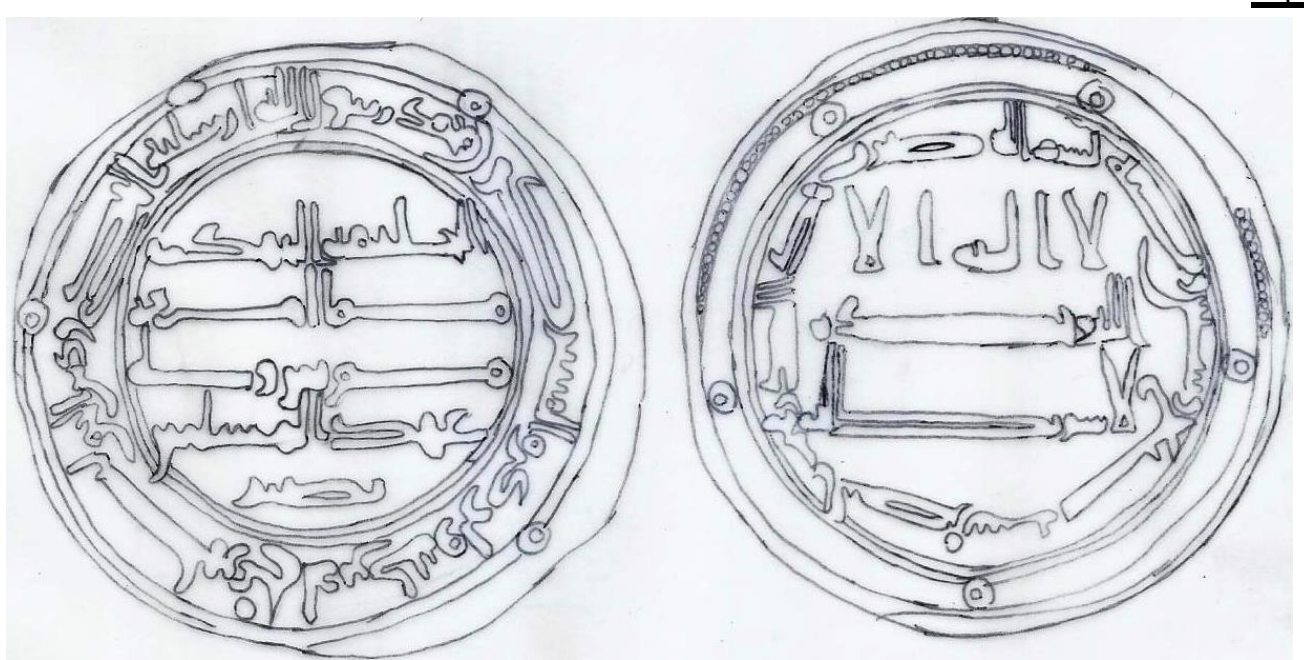

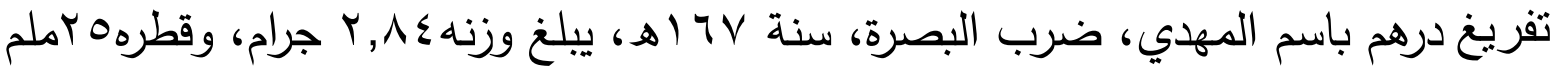



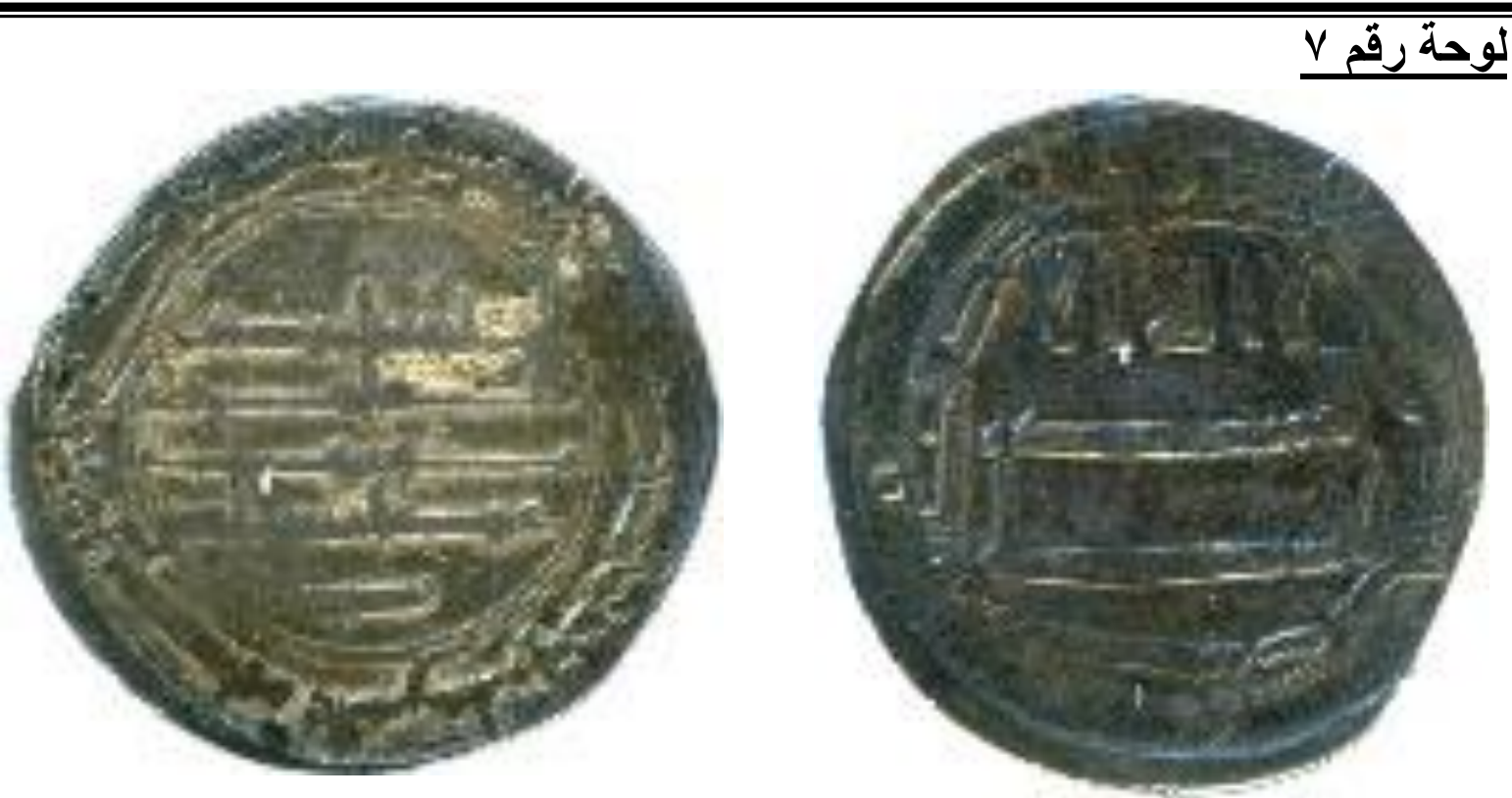

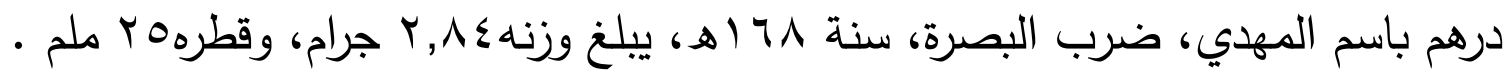
Collection: American Numismatic Society, NO, 1917.215.227.

شكل رقم
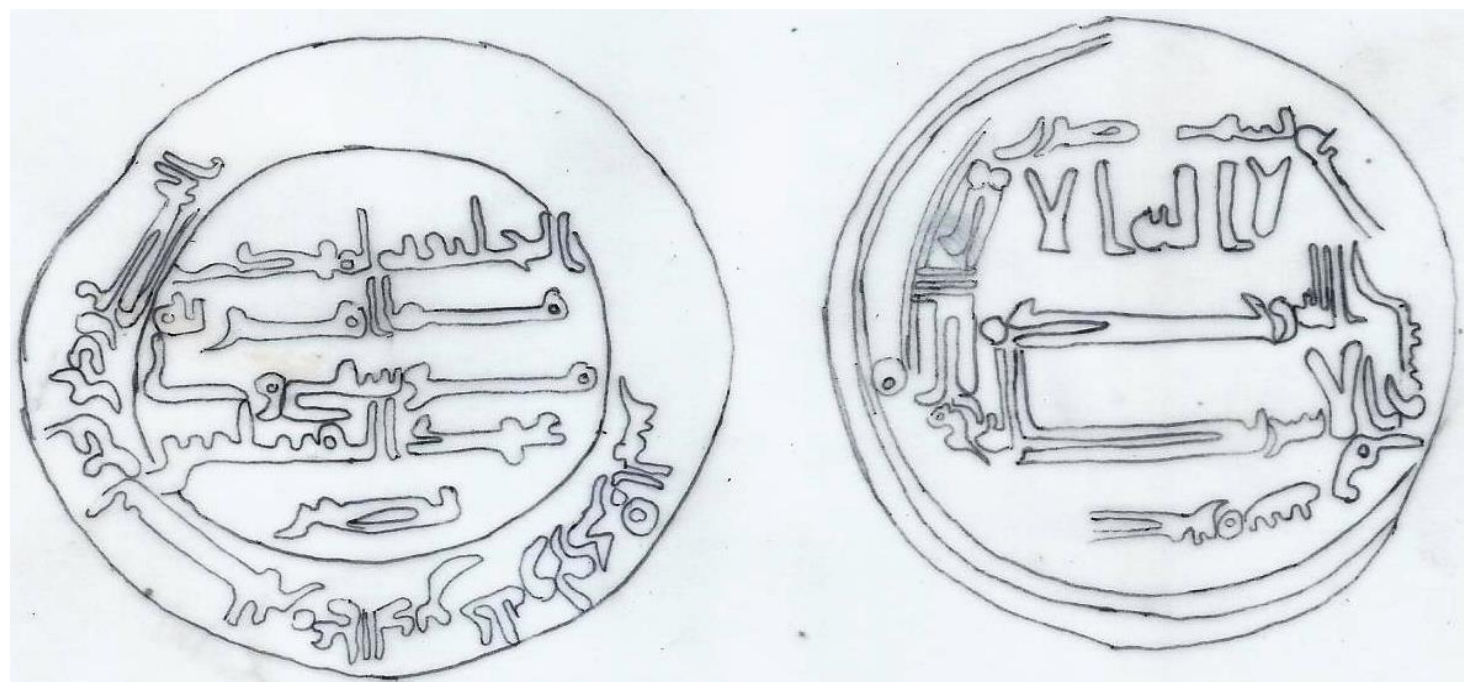

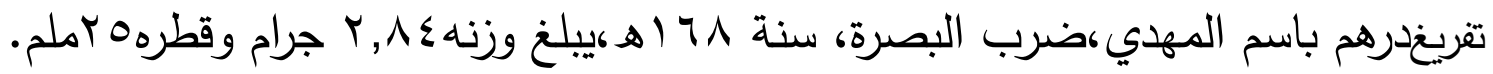



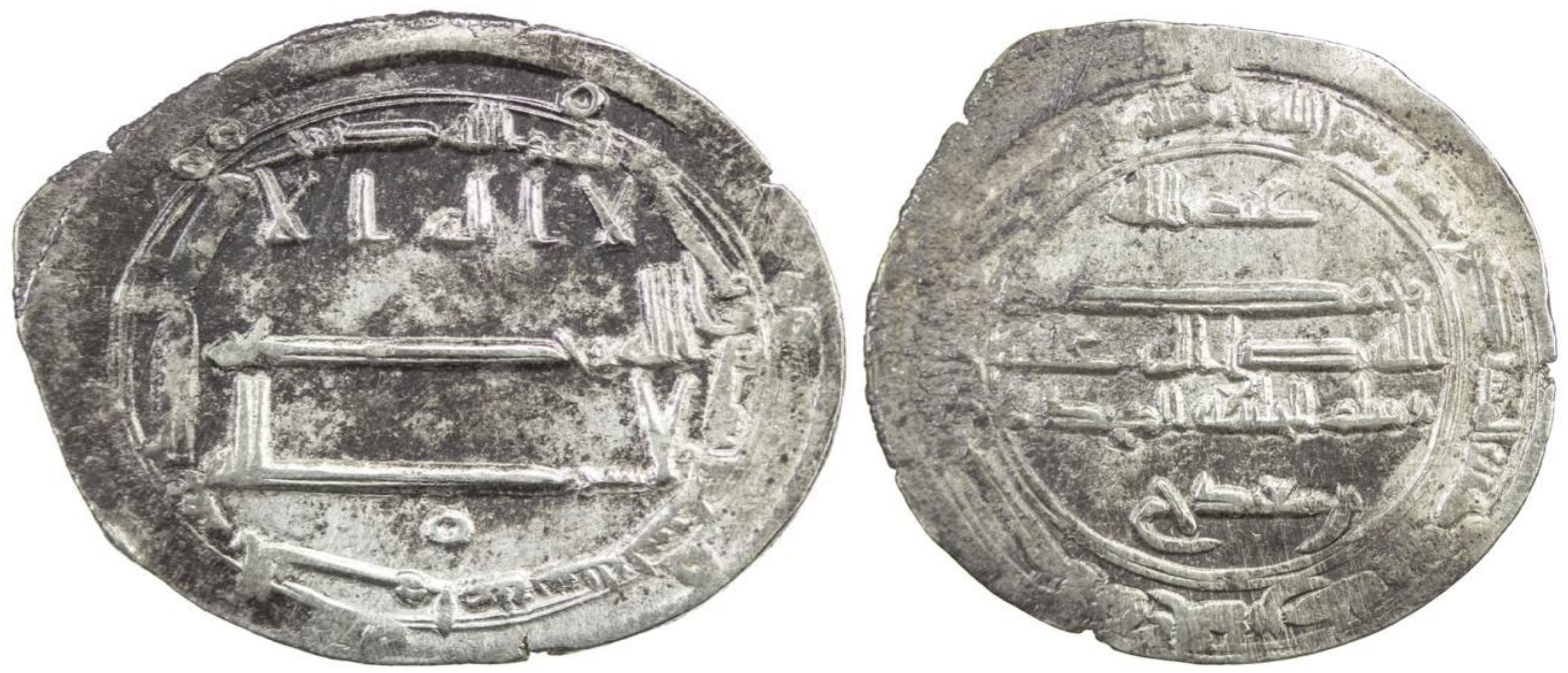

درهم باسم المهدي، ضرب اليمامة، سنة 79 أهـ، يبلغ وزنه بو. ج جرام.

Stephen Album,Auction 25, Lot 232
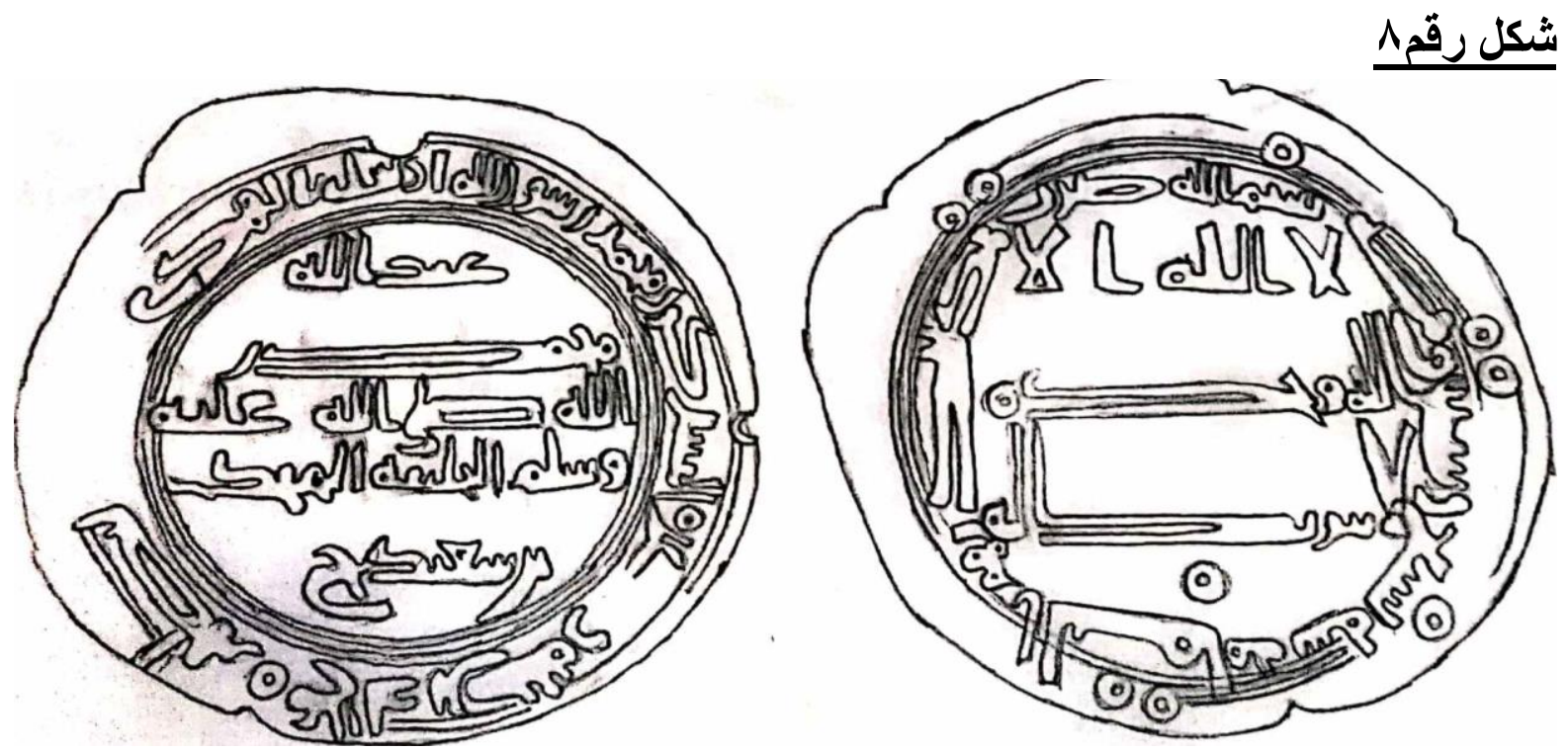

تفريغدرهم باسم المهدي، ضرب اليمامة، سنة 7 (هـ، ييلغ وزنه ب . ج جرام. 

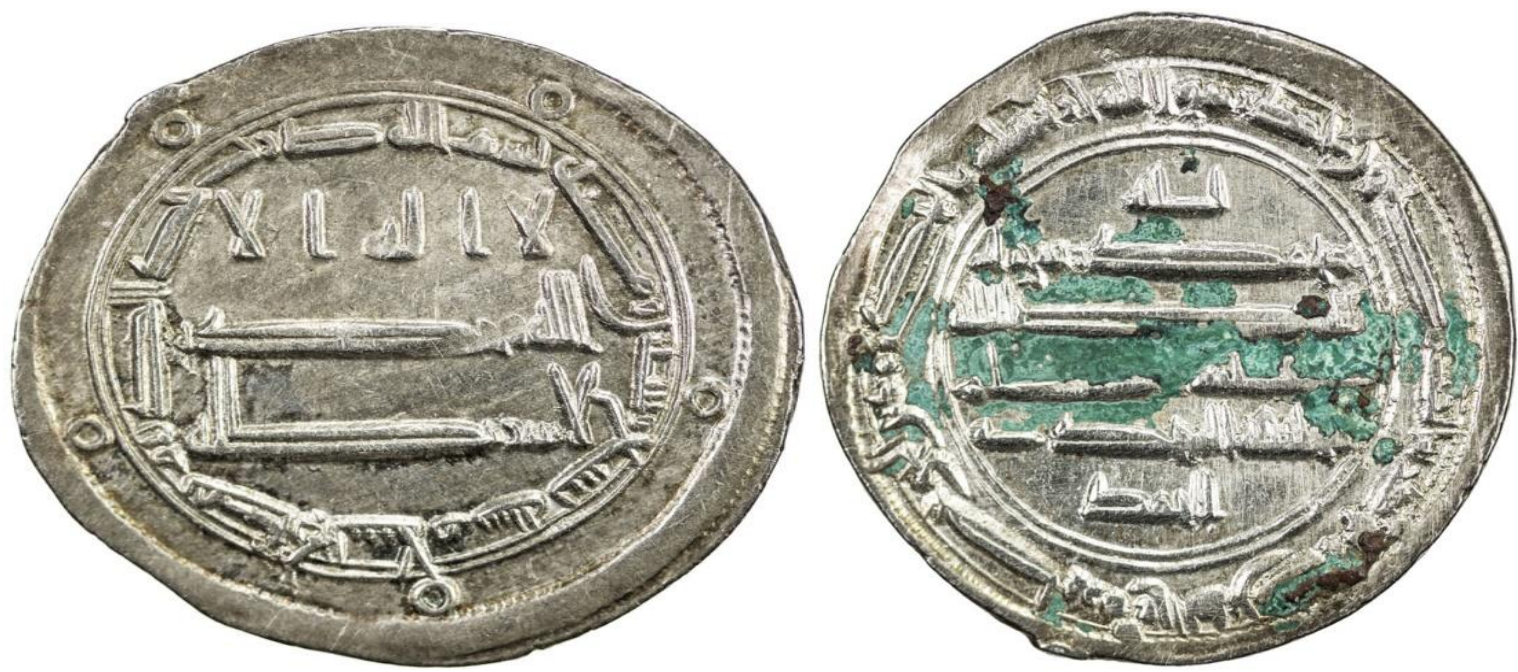

درهم باسم المهي، ضرب قصر السلام، سنة 79 أهـ، يبلغ وزنه90. ج جرام.

Stephen Album, Auction ,26 Lot. 206

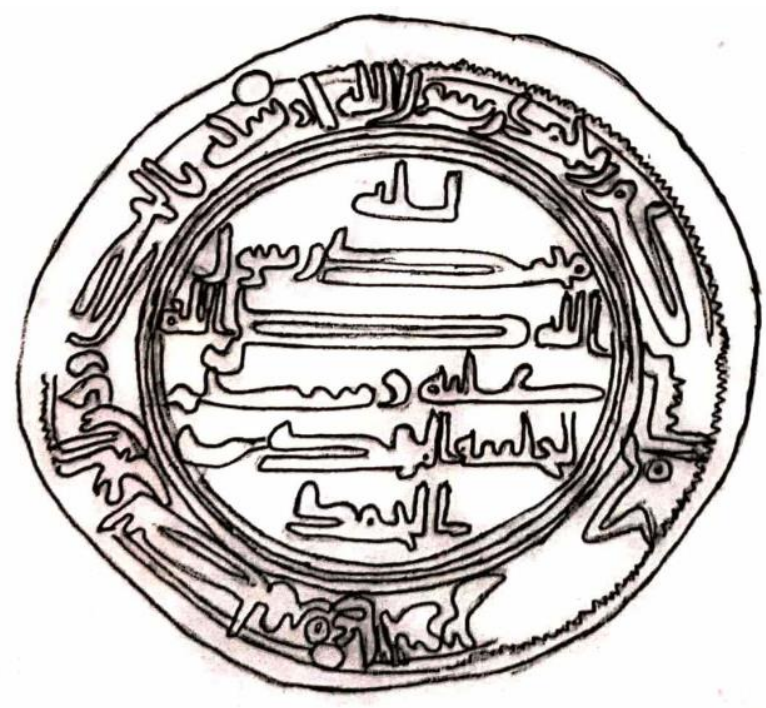

شكل رقمو

$$
\text { تغريغدرهم باسم المهدي، ضرب قصرالسلام، سنة } 79 \text { اهـ، يبلغ وزنه 90. جرام. }
$$



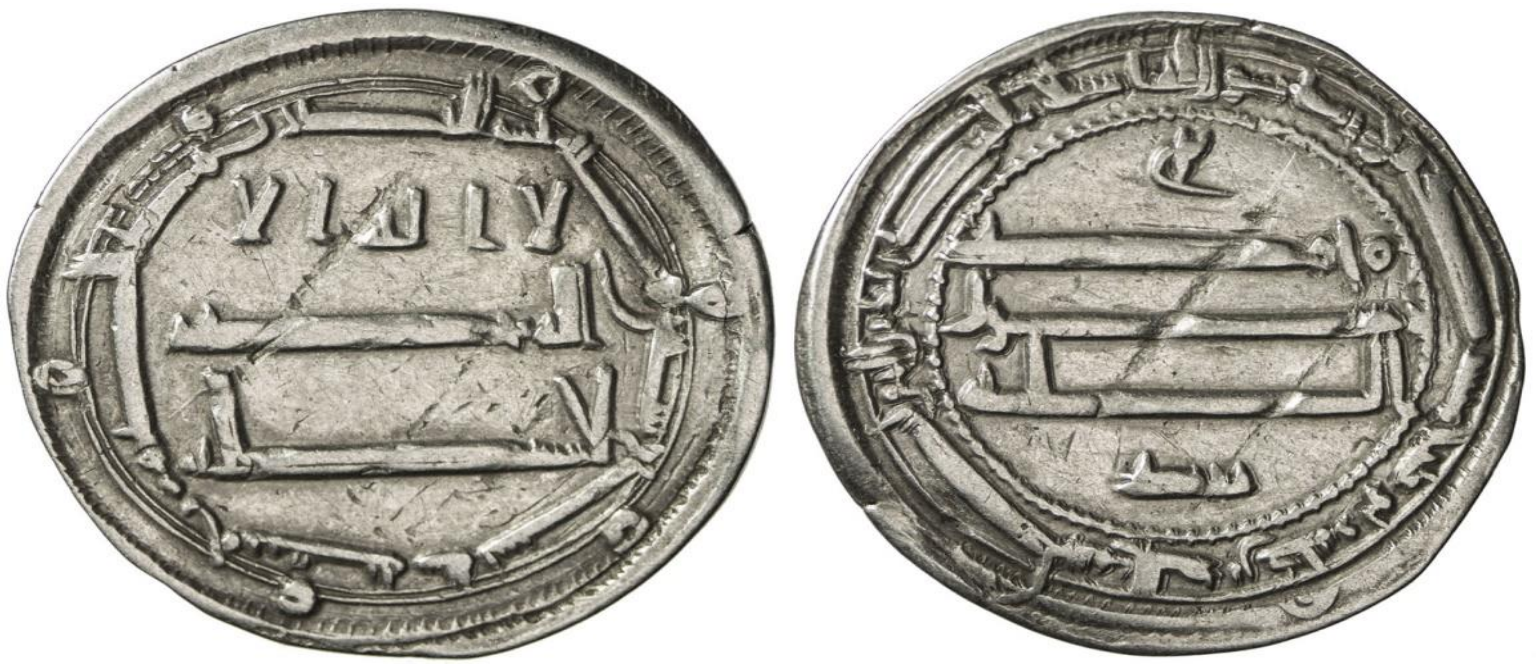

درهم باسم المهدي، ضرب افريقية، سنة 79 اهـ، يبلغ وزنهه ج. ج جرام.

Stephen ALBUM Auction 26 Lot 208
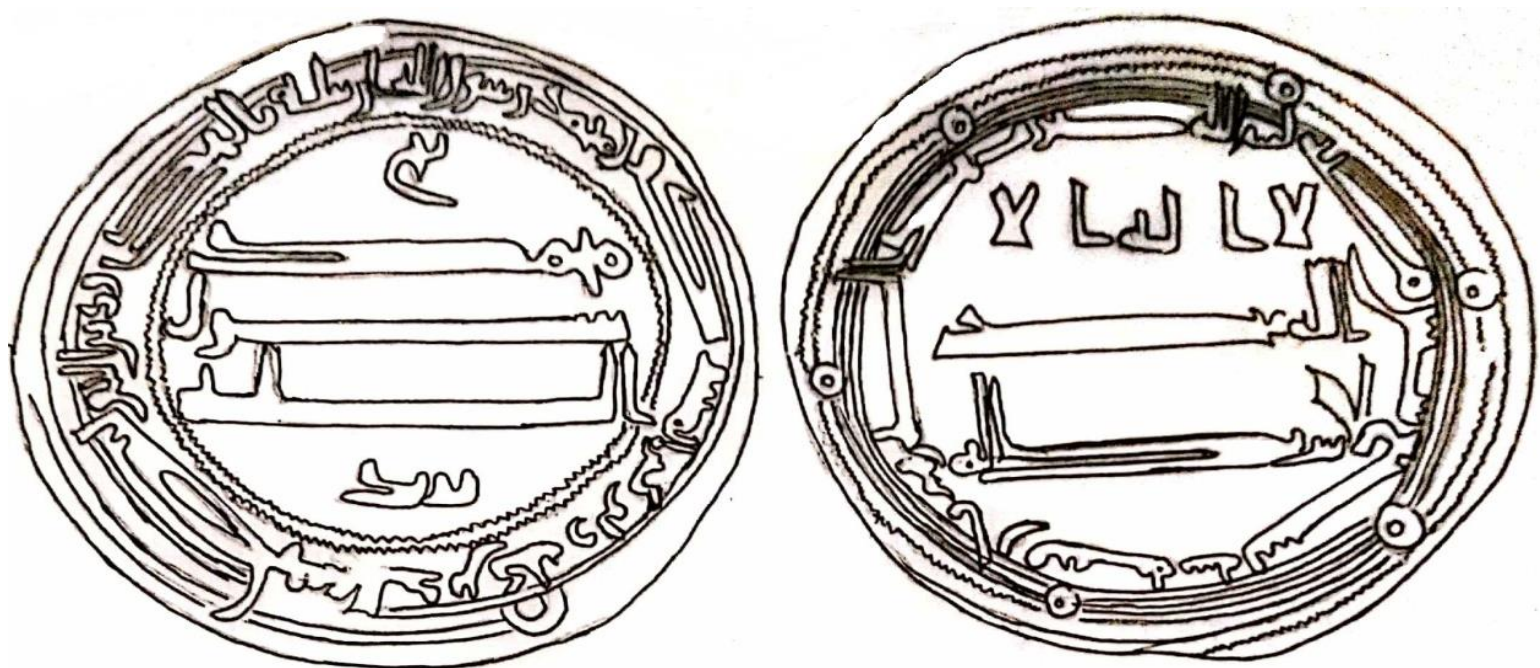

تفريغ درهم باسم المهدي، ضرب افريقية، سنة 79 اهـ، يبلغ وزنهه ج. جرام. 

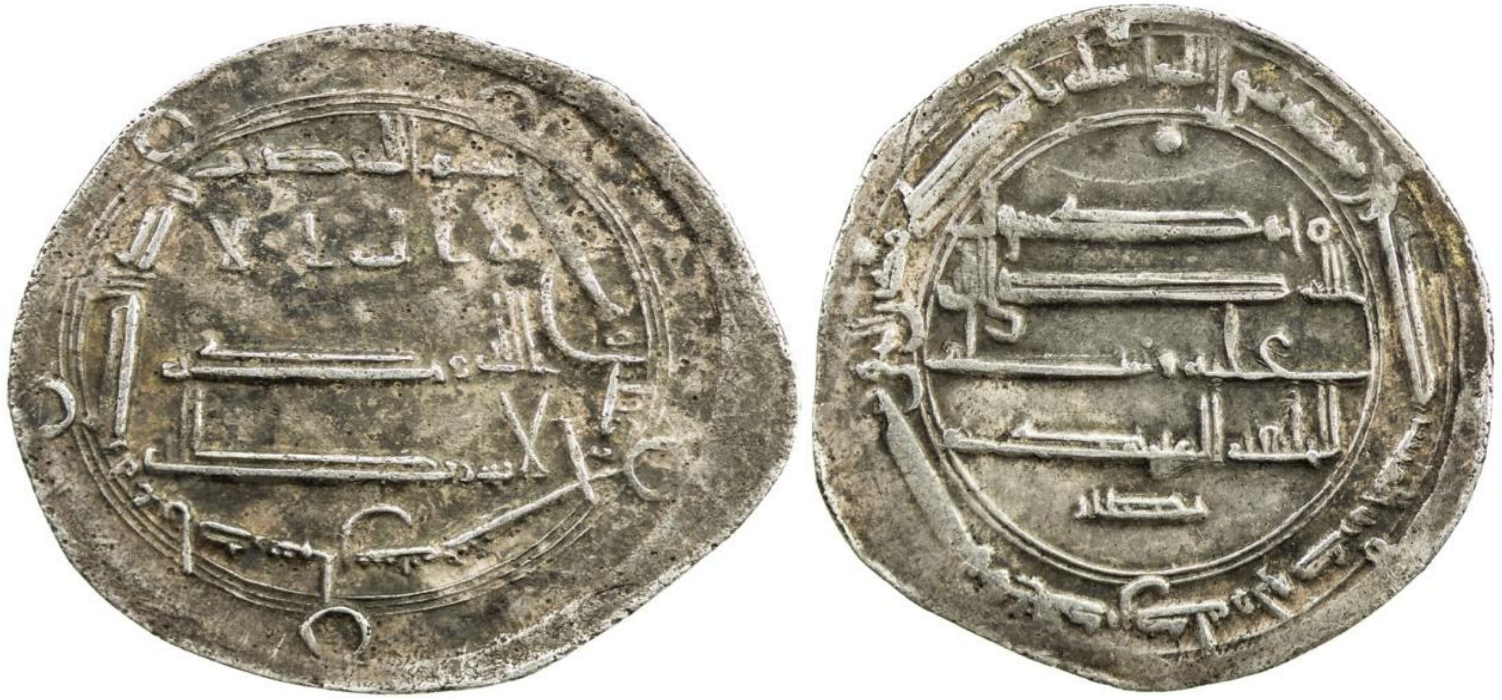

درهم باسم المهدى، ضرب اذريبجان، سنة 7 (اه، يبلغ وزنهــــ جرام. Stephen ALBUM Auction 26 Lot 207 شكل رقم 11
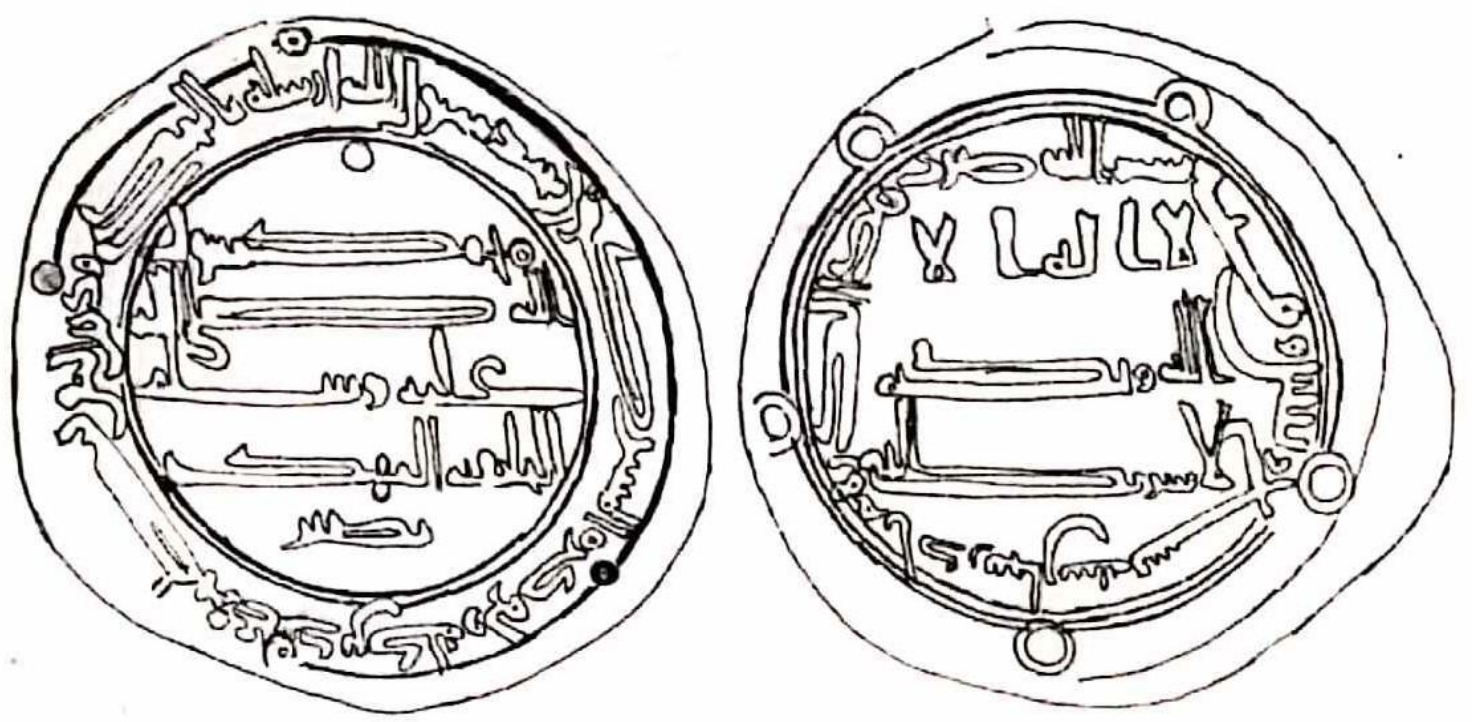

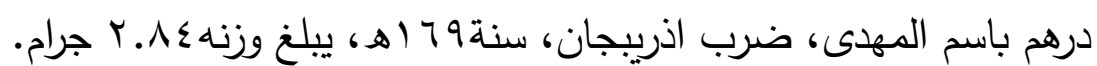


لوحة رقم
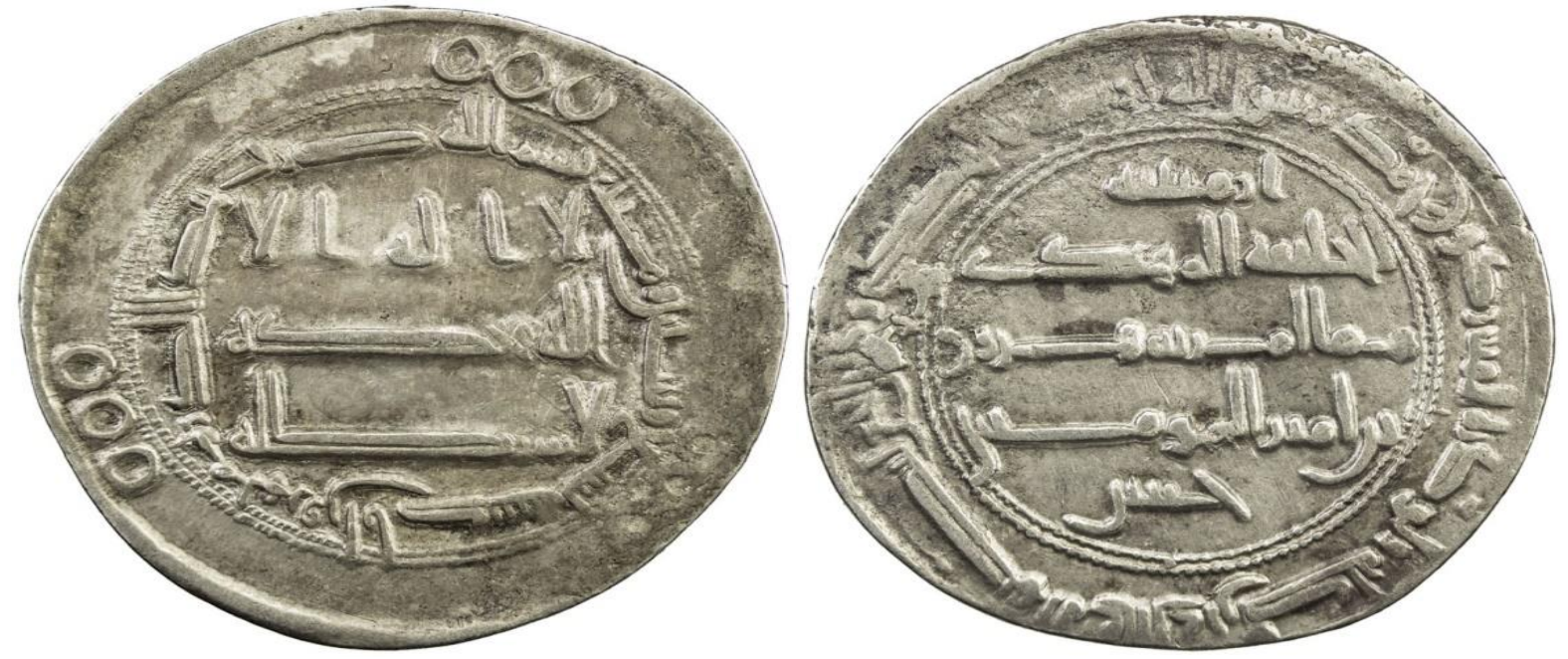

درهم باسم المهدي، ضرب هارون آباد، سنة 19 أهـ يبلغ وزنه . . . جرام.

Stephen Album,Auction,26,Lot.205

شكل رقمر
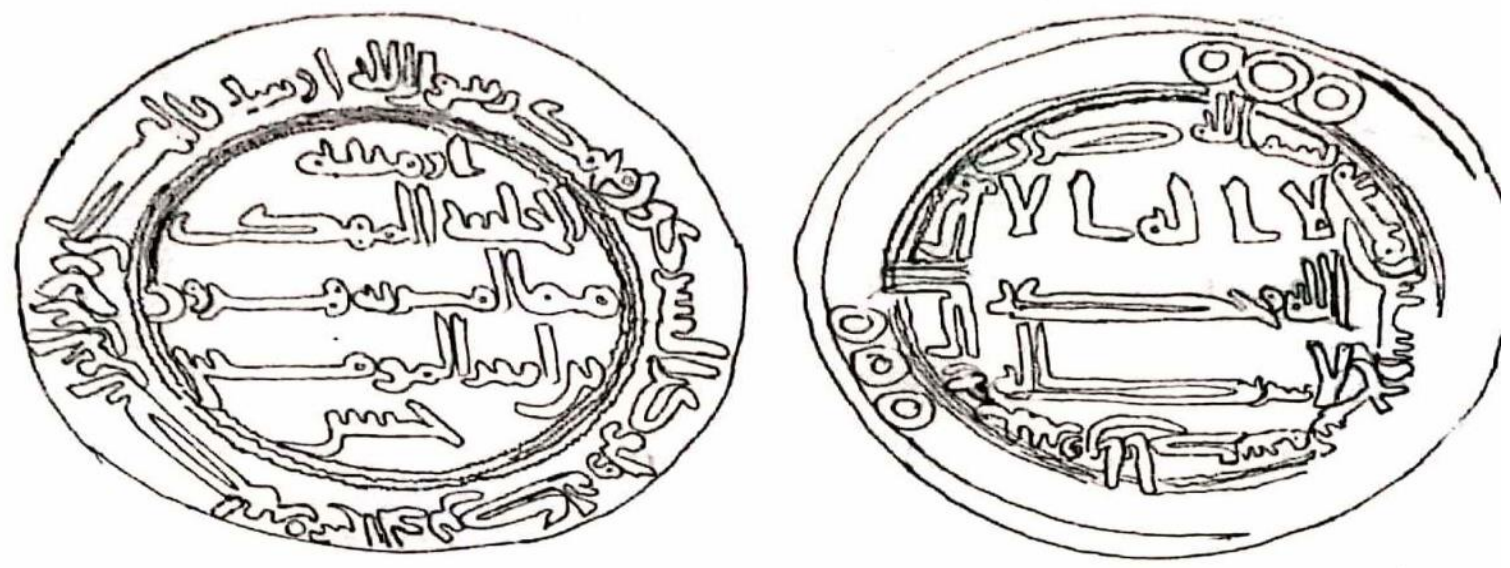

باسم المهدي، ضرب هارون آباد، سنة 19 أهـ، يبلغ وزنه . .9 جرام. • البغـدادى (الحـافظ أبـى بكـر أحمـد بـن على

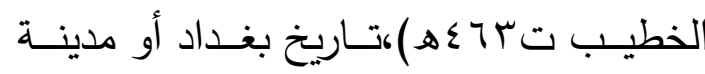
السلام، ج^، مصر ، اسبو (م.

• ابن تغري بردي (جمال الدين أبي المحاسن يوسف ت ع \& هـ)، النجوم الزاهرة في ملوك مصـر والقــاهرة، جـ Y، دارالكتـب، القـاهرة،

د/ت.

$$
\begin{aligned}
& \text { • ابن الاثير (أبى الحسن على بن أبى الكرم } \\
& \text { الثـيبانى ت . بآهـ)،الكامـلـ فـي التـاريخ، } \\
& \text { مراجعـة، حمحد يوسـف الـدقاق، جه، بيـروت، } \\
& \text {. } 919 \mathrm{~V}
\end{aligned}
$$




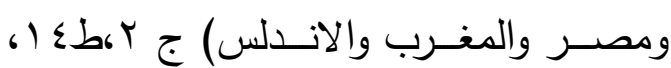

$$
\text { القاهرة - بيروت، و9 } 99 \text { (م. }
$$

ع. خلف فـارس الطراونـة، نـاهض عبــ الـرازق

دفتر : المسـكوكات وقـراءة التاريخ،عمـان-

$$
\text { الأردن، ع } 99 \text { (م. }
$$

ه. رأفت النبراوى، التاريخ الهجرى على النقود

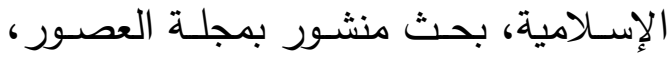

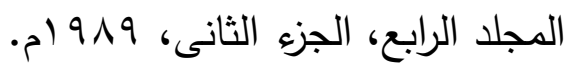

7 ـ الشيماء عبداللطيف جادالله خحم، إمارة كرمان

تحت حكم المغول(9 (آ_r • Vهـ )، رسـالة ماجسـتير ، كليـة دار العلـوم، فـرع الفيـوم،

$$
\text { جامعة القاهرة، ع . . بم. }
$$

V. عاطف منصور محمد رضضان،موسوعة النقود

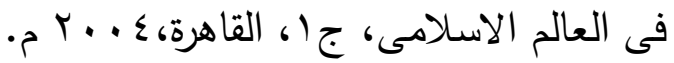

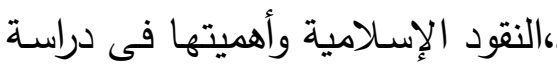
.$\wedge$

التاريخ والآثاروالحضـارة الاسـلامية، القاهرة،

$$
\text { طr، 11 }
$$

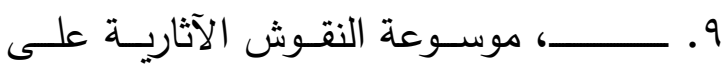

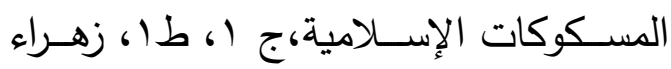

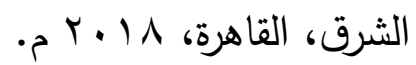

• 1 . عبــــ الواحـــ الرمضــانى، المســكوكات

الفضية العباسية فى مجموعة مركز البحوث

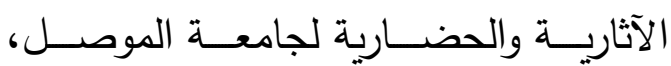

آداب الرافــدين، العــدد الســـادس، 90

$$
\text { ه } 9 \text { ه }
$$

ا1 ا. فــرج الله يوســف، الآيات القرآنيــة علــى

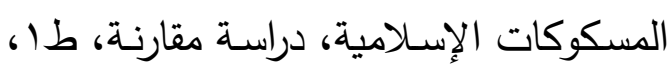

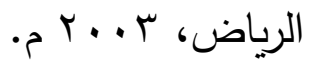

• الذهبى ( الإمـام شمس الدين محمد بـن أحمد

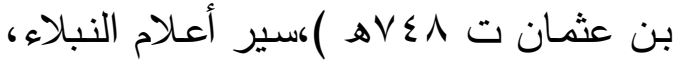

$$
\text { ج9، طا ال، بيروت، } 999 \text { (م. }
$$

الطبرى( أبـى جعفر محمد بـن جريـر الطبـرى

ت • (1 هـ)،تاريخ الرسل والملوك المعروف

بتاريخ الطبرى، ج^، طץ، القاهرة، 979

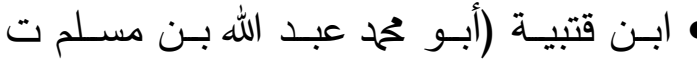

Tـ TVT )، المعارف، تحقيق، ثروت عكاشـة،

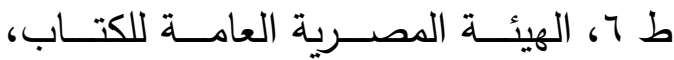

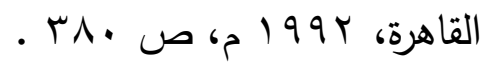

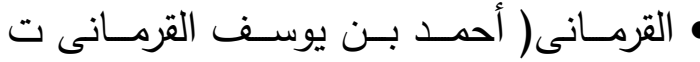

9 1 • (اهـ)، أخبـار الـدول وآثـار الأول في

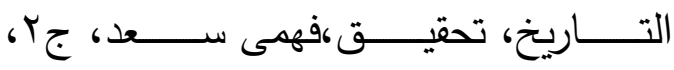

بيروت، بr 99 (م.

• يـاقوت الحموى(شـهاب الـدين أبـى عبـد الله

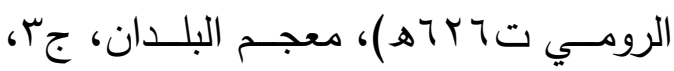

$$
\text { بيروت س99 19 م. }
$$

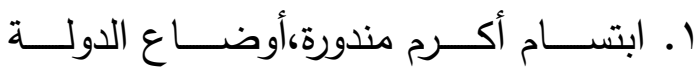

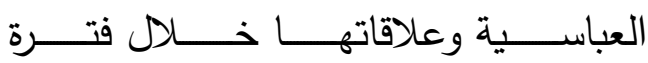

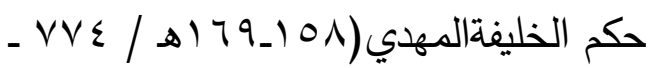

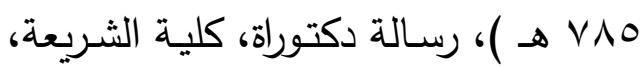
جامعة أم القرى، اكو 999 (م. r. اسحاق تحمد رباح ، تطور النقود الاسـلامية حتى نهاية عهد الخلافة العباسية ،عمان .$r \ldots \Lambda_{6}$

". حسـن إبـراهيم حسـن ، تـاريخ الاســلام

السياسـي والـدينى والثقــافى والاجتمـاعى

( العصــر العباســى الأول فـي الثــرق 
18. Nicholas Lowic:early Abbasid Coinage Atype Corpus(132-218 H - 750-833 AD), puplished by Britsh Museum, London ,1996.

19. Norman d. Nicol Raafat Elnabrawy,Jerel.bacharach:Catalog of the slamic Coins Glass

Weights, Dies and Medals in the Egyptian National library Cairo 1982.

20. RichrdKimber:The Succession to the Caliph Musa alHadi-Journal of American Oriental Society ,vol.121 No.3, 2001.

\section{المزادات والمواقع الاكتتونية :}

21. http://www.baldwin.com

22. http://www.sixbid.com

23. http://www.numisbids.com

24. http://www.stevealbum.com

25. www.Zeno.ru

26. https://www.numisbids.

27. American Numismatic Society .http://numismatics.org
با. ـ محمد أبــوالفرج العـش، النقــود العربيــة

الاســلامية، ج)، طب، مراجعـة، إبـراهيم

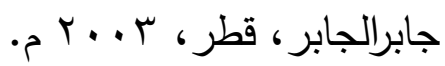

با ـ كى ليسترنج، بلـدان الخلافـة الثـرقية، ترجمـة، بشيرفرنسـيس وكـوروكيس عـواد،

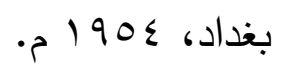

ـ ا. محمدعبـد السـتارعثمان، دلالات سياسـية

دعائية للآثار الإسلامية فى عهد الخليفة

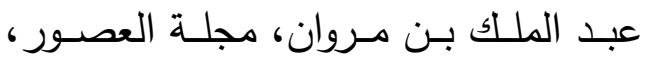

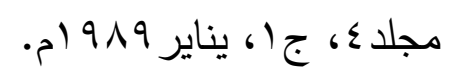

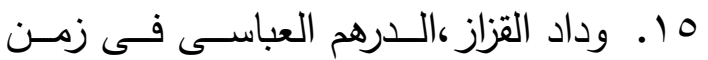

الخليفتين المهدى والهادى، بحث منشور

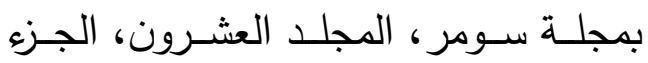

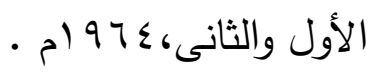

16. A.ShamsEshragh:Silver Coinage Of the Calphs, executed by Estack Press, Second edition ,2010 .

17. Lane-poole:Catalouge of Oriental Coins in the British Museum vol.1, London,1875 . 